\title{
O ZINCO COMO PROMOTOR DO CRESCIMENTO DE SUÍNOS FM RECRIA
}

\author{
FÁBIO GUILHERME AUTRAN BOTELHO
}

Engenheiro Agrônomo

Orientador: Prof. Dr. Valdomiro Shigueru Miyada

Dissertação apresentada à Escola
Superior de Agricultura "Luiz de
Queiroz", da Universidade de são
Paulo, para obtenção do título de
Mestre em Agronomia, Área de
Concentração: Ciência Animal e
Pastagens.

P I R A C I C A B A

Estado de São Paulo - Brasil

Setembro - 1996 


\title{
Dados Internacionais de Catalogação na Publicação (CIP) DIVISÃO DE BIBLIOTECA E DOCUMENTAÇÃO - Campus "Luiz de Queiroz"/USP
}

\author{
Botelho, Fábio Guilherme Autran \\ O zinco como promotor do crescimento de suinos em recria / Fábio Guilherme \\ Autran Botelho. - - Piracicaba, 1996. \\ $66 \mathrm{p}$. \\ Dissertaçāo (mestrado) - - Escola Superior de Agricultura Luiz de Queiroz, \\ 1996. \\ Bibliografia.
}

1.Estimulante do crescimento 2. Nutriçāo animal 3. Suino 4. Zinco I. Título

CDD 636.4085 


\title{
O ZINCO COMO PROMOTOR DO CRESCIMENTO DE SUÍNOS FM RECRIA
}

\author{
FÁBIO GUILHERME AUTRAN BOTELHO
}

Aprovada em 19.11.1996.

Comissão julgadora:

Prof. Dr. Valdomiro Shigueru Miyada ESALQ/USP

Prof. Dr. José Eurico Possebon Cyrino ESALQ/USP Dr. Gustavo Júlio M. M. de Lima CNPSA/EMBRAPA

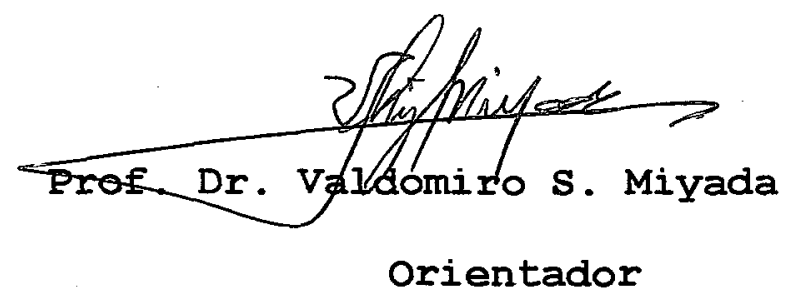


$A$

ATHOS HENRIQUE GUEDES BOTELHO E THELMA AUTRAN BOTELHO, MEUS PAIS, "OS BRAVOS",

DEDICO.

E 'A MEMÓRIA DE MEUS AVÓS, ATHOS FÁBIO ROMANO BOTELHO E AGOSTINHO GUILHERME VIEGAS AUTRAN. 


\section{AGRADECIMENTOS :}

- Prof. Dr. Valdomiro Shigueru Miyada, meu orientador, pelos 10 anos de convivência, amizade e oportunidades, além do seu conhecimento técnico;

- Profs. Drs. José Fernando Machado Menten e José Eurico Possebon Cyrino pelas "dicas" e amizade;

- Funcionários e estagiários do setor de suinocultura do Departamento de Zootecnia da ESALQ (Srs. Ventura, Pires, irmãos Galvão, Netão);

- Capes - Fundação Coordenação de Aperfeiçoamento de Pessoal de Nível Superior, pela concessão da bolsa de estudos. 
SUMÁRIO

\section{Página}

IISTA DE TABELAS.................... vi

LISTA DE FIGURAS.................... vii

LISTA DE TABELAS DO APÊNDICE.............. ix

RESUMO .......................... $\mathrm{x}$

SUMMARY.................................. xii

1. INTRODUÇÃO $\ldots \ldots \ldots \ldots \ldots \ldots \ldots \ldots \ldots \ldots \ldots \ldots \ldots \ldots$

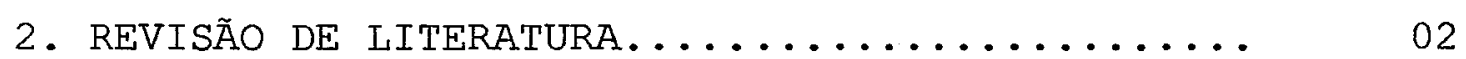

2.1. Metabolismo do zinco................ 02

2.2. Funções metabólicas do zinco........... 04

2.3. Interações que afetam a absorção e o metabolismo do zinco............... 05

2.4. Exigências dos suínos em zinco.......... 07

2.5. Efeitos de altos niveis de zinco suplementar na ração sobre o controle da

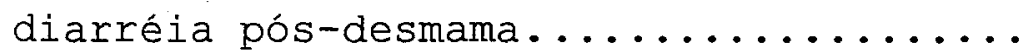

2.6. Efeitos de altos níveis de zinco suplementar na ração sobre o desempenho

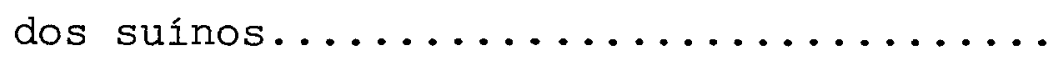

2.7. Modos de ação do zinco como promotor do

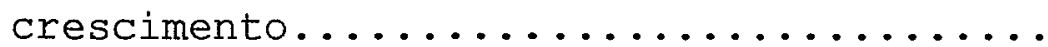

2.8. Impacto ambiental causado pelo zinco nos

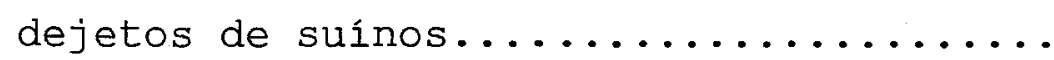




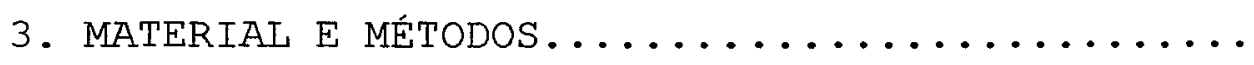

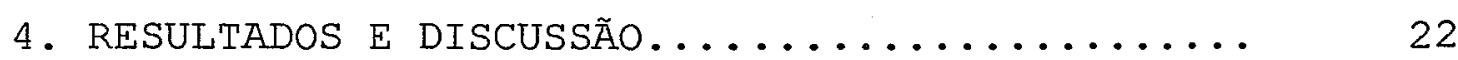

4.1. Características de performance......... 22

4.2. Componentes sanguíneos e plasmáticos.... 35

5. CONCLUSÕES....................... 38

REFERÊNCIAS BIBLIOGRÁFICAS............... 44

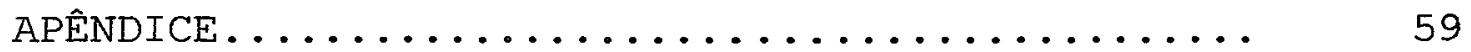


1 Composição percentual da ração basal...... dos leitões em recria alimentados com rações suplementadas com zinco...........

3 Efeitos da suplementação de zinco dietético sobre os parâmetros ganho diário de peso (GDP, g), consumo diário de ração (CDR, g) e conversão alimentar (CA) ........... 41

4 Média dos componentes sanguíneos e plasmáticos dos leitões em recria alimentados com rações suplementadas

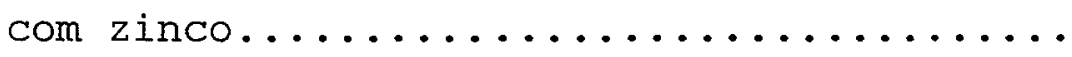

5 Efeitos da suplementação de zinco dietético sobre os componentes sanguineos [hematócrito (Ht, \%) e hemoglobina ( $\mathrm{Hb}$, g/dl)] e plasmáticos [proteína total (Pt, g/dl), albumina (Alb, g/dl) e uréia (Ur, $\mathrm{mg} / \mathrm{dl})]$ 
1 Efeitos dos níveis de zinco suplementar sobre o ganho diário de peso (GDP, g), consumo diário de ração (CDR, g) e conversão alimentar (CA) de leitões em recria na primeira semana de experimentação..................

2 Efeitos dos níveis de zinco suplementar sobre o ganho diário de peso (GDP, g), consumo diário de ração ( $C D R, g$ ) e conversão alimentar (CA) de leitões em recria nas duas primeiras semanas de experimentação..................

3 Efeitos dos níveis de zinco suplementar sobre o ganho diário de peso (GDP, g), consumo diário de ração (CDR, g) e conversão alimentar (CA) de leitões em recria nas três primeiras semanas de

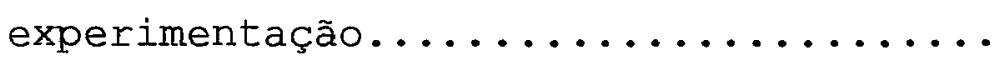

4 Efeitos dos niveis de zinco suplementar sobre o ganho diário de peso (GDP, 
g), consumo diário de ração (CDR, g) e conversão alimentar (CA) de leitões em recria durante a terceira e quarta semanas de experimentação............

5 Efeitos dos níveis de zinco suplementar sobre o ganho diário de peso (GDP, g) e consumo diário de ração (CDR, g) de leitões em recria durante as quatro semanas de experimentação.....

6 Efeitos dos níveis de zinco suplementar sobre a proteína total (Pt, $g / d l$ ), a albumina (Alb, g/dl) e uréia (Ur, mg/dl) do plasma de leitões em recria........ 
LISTA DE TABEIAS DO APENDICE

TABELA N $\mathrm{N}^{\mathrm{O}}$

PÁGINA

A1 Performance dos leitões na primeira semana de experimentação............

A2 Performance dos leitões nas duas primeiras semanas de experimentação (1 a 14 dias)..

A3 Performance dos leitões nas três primeiras semanas de experimentação (1 a 21 dias).....................

A4 Performance dos leitões durante as duas últimas semanas de experimentação

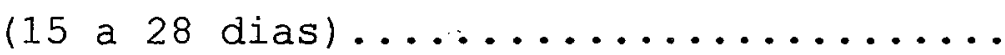

A5 Performance dos leitões durante as quatro semanas de período experimental

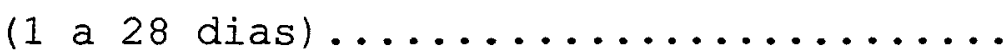
Componentes sanguíneos dos leitões: hematócrito (Ht, 号) e hemoglobina (Hb, $g / d 1) \ldots \ldots \ldots \ldots \ldots \ldots \ldots \ldots \ldots . \ldots \ldots \ldots . \ldots \ldots$

A7 Componentes plasmáticos dos leitões: proteína total (Pt, $g / d l$ ), albumina $(A l b, g / d l)$ e uréia $(U r, g / d l) \ldots . . . .$. 
O ZINCO COMO PROMOTOR DO CRESCIMENTO DE SUÍNOS EM RECRIA

\section{Autor: FÁBIO GUILHERME AUTRAN BOTELHO \\ Orientador: Prof. Dr. VALDOMIRO SHIGUERU MIYADA}

RESUMO

O presente estudo de 28 dias de duração teve como objetivo avaliar altos níveis de zinco ( $\mathrm{Zn}$ ) suplementar como promotor do crescimento de suínos na fase de recria. Foram utilizados 150 leitões, machos e fêmeas, puros ou cruzados, das raças Landrace, Large White e Duroc, desmamados aos 28 dias de idade média, com peso médio inicial de $6,85 \mathrm{~kg}$, para testar níveis supranutricionais de $0,750,1500,2250$ e 3000 ppm de $\mathrm{Zn}$, na forma de óxido de zinco (Zno) fornecido durante 28 dias.

A ração basal era composta de milho (56\%), farelo de soja (26\%), leite em pó desnatado (5\%), soro de leite desidratado (5\%), açúcar (4\%), óleo de soja. (1\%), além dos suplementos minerais e vitamínicos, proporcionando 18,89\% de $\mathrm{PB}$ e $3329 \mathrm{kcal} \mathrm{EM} / \mathrm{kg}$ de ração. A ração e a água foram fornecidas à vontade durante todo o período experimental de 28 dias. 0 delineamento experimental foi 0 de blocos completos casualizados, com 8 repetições/tratamento, sendo 6 blocos com 4 animais/baia e 2 blocos com 3 animais/baia.

Semanalmente foram feitas pesagens individuais dos leitões e registrados o consumo de ração da baia para o cálculo da conversão alimentar. No final de cada repetição foram coletadas amostras de sangue de 2 animais/unidade experimental, para a determinação dos parâmetros sanguíneos e plasmáticos. 
Nas duas primeiras semanas de experimentação, o Zn proporcionou respostas lineares do ganho diário de peso $(P<0,00001 ; 138,141,172,223$ e $257 \mathrm{~g} ; \mathrm{GDP}=121,925+$ $\left.0,004285 \mathrm{X} ; \mathrm{R}^{2}=0,94\right)$, no consumo diário de ração $(P<0,00001 ; 325,314,356,410$ e $443 \mathrm{~g} ; \mathrm{CDR}=303,125+$ 0,0441833X; $\left.R^{2}=0,90\right)$ e na conversão alimentar $(P<0,0005$; $2,23,2,21,2,19,1,90$ e 1,76; $\mathrm{CA}=2,309933$ - 0,000168X; $\left.\mathrm{R}^{2}=0,67\right)$.

No período total de experimentação, o $\mathrm{Zn}$ suplementar determinou respostas linear $(P<0,0001)$ e cúbica $(P<0,004)$ do ganho diário de peso $(299,299,340,398$ e 385 g; GDP = $299,519643-0,0672718 \mathrm{X}+0,00009832 \mathrm{X}^{2}-0,000000022 \mathrm{X}^{3} ; \mathrm{R}^{2}=$ $0,99)$ e também linear $(P<0,0001)$ e cúbica $(P<0,003)$ do consumo diário de ração $(589$, 581, 653, 756 e 753 g; CDR = $590,45-0,1261667 \mathrm{X}+0,00017044 \mathrm{X}^{2}-0,000000037 \mathrm{X}^{3} ; \mathrm{R}^{2}=$ $1,00)$, sem influenciar $(P>0,05)$ a conversão alimentar.

Em relação aos componentes sanguíneos, o $\mathrm{Zn}$ não influenciou $(P>0,05)$ os parâmetros hematócrito e hemoglobina, mas apresentou efeitos quadráticos $(P<0,003$ e $\mathrm{P}<0,0004)$ para os níveis plasmáticos de proteína total $(5,4,5,6,5,7,5,7$ e $5,4 \mathrm{~g} / \mathrm{dl} ; \mathrm{Pt}=5,398571+0,0004255 \mathrm{X}$ - 0,00000014X $\mathrm{X}^{2}$. $\left.\mathrm{R}^{2}=0,95\right)$ e albumina $(3,2,3,3,3,4,3,4$ e $3,0 \mathrm{~g} / \mathrm{dl} ; \mathrm{Alb}=3,2075+0,00035 \mathrm{X}-0,00000013 \mathrm{X}^{2} ; \mathrm{R}^{2}=$ 0,83). O Zn determinou, ainda, uma resposta linear $(\mathrm{P}<0,002)$ do conteúdo de uréia plasmática $(24,27,29,30$ e $\left.31 \mathrm{mg} / \mathrm{dl} ; \mathrm{Ur}=24,625+0,0024333 \mathrm{X} ; \mathrm{R}^{2}=0,94\right)$.

Assim, determinou-se que a suplementação com 2250 ppm de $\mathrm{Zn}$ continuadamente por quatro semanas pós-desmama proporcionou as melhores respostas para ganho diário de peso e consumo diário de ração dos leitões em recria. 0 melhor desempenho com o nível de 3000 ppm nas três 
primeiras semanas pós-desmama não se manteve até o final do experimento, muito provavelmente devido a um efeito tóxico decorrente do uso prolongado do nível mais elevado de $\mathrm{Zn}$. Os valores máximos observados para os componentes proteína total e albumina obtidos com o nível de 1500 ppm de $\mathrm{Zn}$ constitui outra evidência de que os níveis mais elevados de Zn suplementar, por períodos prolongados, podem ter efeitos negativos no metabolismo animal. 


\section{ZINC AS A GROWTH PROMOTER OF WEANLING PIGS}

\section{Author: FÁBIO GUILHERME AUTRAN BOTELHO}

Adviser: Prof. Dr. VALDOMIRO SHIGUERU MIYADA

\section{ABSTRACT}

An experiment, involving 150 crossbred weanling pigs (Landrace $\mathrm{x}$ Large White $\mathrm{x}$ Duroc) with $6.85 \mathrm{~kg}$ average initial live weight, was carried out to evaluate the effect of five dietary supplemental zinc levels - 0, 750, 1500, 2250 and 3000 ppm - (as zinc oxide) on performance and on blood and plasma components.

The basal diet $(18.89 \%$ crude protein and $3329 \mathrm{kcal}$ $\mathrm{DE} / \mathrm{kg}$ ) was based on corn (56\%), soybean meal (26\%), dried skim milk (5\%), dried whey (5\%), sucrose (4\%), soybean oil (1), and supplemented with minerals and vitamins. Feed and water were given "ad libitum" to pigs during the 28-day experimental period. A randomized complete block design with 8 replications and 3 or 4 animals/experimental unit (pen) was utilized. Pigs were weighed individually and feed intake/pen was registered weekly. At the end of experimental period, blood samples were collected from anterior vena cava of 2 pigs/pen after a 5-hour fasting period.

In the first two weeks, supplemental dietary zinc resulted in a linear response of average daily gain 
$(\mathrm{P}<.00001 ; 138,141,172,223$ and $257 \mathrm{~g} ; \mathrm{ADG}=121.925+$ $\left..004285 \mathrm{X} ; \mathrm{R}^{2}=.94\right)$, daily feed intake $(\mathrm{P}<.00001 ; 325,314$, 356,410 and $443 \mathrm{~g} ; \mathrm{ADFI}=303.125+.0441833 \mathrm{X} ; \mathrm{R}^{2}=.90$ ) and feed conversion ( $P<.0005 ; 2.23,2.21,2.19,1.90$ and $\left.1.76 ; \mathrm{F} / \mathrm{G}=2.309933-.000168 \mathrm{X} ; \mathrm{R}^{2}=.67\right)$.

Considering the total experimental period, supplemental dietary zinc resulted in a linear $(P<.00001)$ and cubic $(\mathrm{P}<.004)$ response of average daily gain (299, 299, 340, 398 and $385 \mathrm{~g} ; \mathrm{ADG}=299.519643-.0672718 \mathrm{X}+$ $\left..00009832 \mathrm{X}^{2}-.000000022 \mathrm{X}^{3} ; \mathrm{R}^{2}=.99\right)$, Iinear $(\mathrm{P}<.00001)$ and cubic $(P<.003)$ response of daily feed intake (589, 581, 653, 756 and $753 \mathrm{~g} ; \mathrm{ADFI}=590.45-.1261667 \mathrm{X}+.00017044 \mathrm{X}^{2}$ - .000000037X $\left.; \mathrm{R}^{2}=1.00\right)$, but no effect $(\mathrm{P}>.05)$ was observed on feed conversion.

For blood parameters, supplemental zinc showed no effect (P>.05) on hematocrit and hemoglobin content. Supplemental zinc resulted in a quadratic effect on plasma total protein $(\mathrm{P}<.003 ; 5.4,5.6,5.7,5.7$ and $5.4 \mathrm{~g} / \mathrm{dl}$; Pt $\left.=5.398571+.0004255 \mathrm{X}-.00000014 \mathrm{X}^{2} ; \mathrm{R}^{2}=.95\right)$ and on plasma albumin $(P<.0004 ; 3.2,3.3,3.4,3.4$ and $3.0 \mathrm{~g} / \mathrm{dl}$; $\left.\mathrm{Alb}=3.2075+.00035 \mathrm{X}-.00000013 \mathrm{X}^{2} ; \mathrm{R}^{2}=.83\right)$, and $\mathrm{a}$ linear increase $(P<.002)$ on plasma urea content $(24,27$, 29,30 and $31 \mathrm{mg} / \mathrm{dl}$; Ur $\left.=24.625+.0024333 \mathrm{X} ; \mathrm{R}^{2}=.94\right)$.

This experiment showed that supplemental zinc can be an effective growth promoter when given at 2250 $\mathrm{ppm}$ in weanling pig diet for $28 \mathrm{-d}$ post-weaning. The best performance in the first three weeks was obtained with 3000 ppm Zn fed piglets. For plasma protein and albumin, the best results were obtained with $1500 \mathrm{ppm} \mathrm{Zn}$. On the other hand, $3000 \mathrm{ppm} \mathrm{Zn}$ fed for four weeks showed a depressive 
effect on performance, which is a indication of zinc toxicity. 


\section{INTRODUÇÃO}

Os agentes antimicrobianos têm sido utilizados amplamente como aditivos para suinos desde os anos 50 . Estes aditivos são incorporados às rações para estimular o crescimento, melhorar a utilização dos alimentos, reduzir a morbidade e a mortalidade e aumentar a eficiência reprodutiva.

Os agentes antimicrobianos que efetivamente melhoram 0 desmpenho dos suínos possuem uma característica em comum: a habilidade em suprimir ou inibir o crescimento de certos microrganismos. A eficácia dos antimicrobianos em melhorar a taxa e eficiência do crescimento têm sido amplamente relatada na literatura, particularmente em animais jovens.

Muitos fatores podem afetar as respostas aos aditivos antibacterianos promotores do crescimento, tais como: o produto, o nível incorporado à ração, as combinações e a rotação entre os antimicrobianos, a composição da ração, a idade dos animais, o período de fornecimento ou a redução do nível dos agentes antimicrobianos, as condições higiênicas da criação e as condições climáticas. Embora seja um nutriente essencial para os suínos, o elemento mineral zinco $(\mathrm{Zn})$ possui propriedades antibacterianas e 
promotoras do crescimento quando utilizado em elevadas concentrações na ração.

o objetivo deste trabalho foi estudar a incorporação de altos níveis de $\mathrm{Zn}$ dietético suplementar, na forma de óxido de zinco ( $\mathrm{nnO}$ ), como promotor de crescimento de suínos em recria. O desempenho foi avaliado através do ganho diário de peso, consumo diário de ração e conversão alimentar, e parâmetros sanguíneos (hemoglobina e hematócrito) e plasmáticos (proteína total, albumina e uréia) dos animais.

\section{REVISÃO DA IITERATURA}

\subsection{Metabolismo do zinco}

- Zn, um nutriente essencial, é absorvido principalmente pelo intestino delgado dos animais. 0 mineral se combina especificamente com a prostaglandina $E_{2}$ ou um metabólitó similar no ilúmen intestinal antes de se dirigir às 'células da mucosa (MILLER ET AL., 1979), onde a transferência do $\mathrm{Zn}$ para as células é regulada pela proteína metalótioneína.

Muitos componentes da ração podem influenciar a absorção do Zn (MILLER ET AL., 1979), que pode ser diminuída pelos níveis de fitatos, cálcio, fibra, fósforo, cobre, cádmio e cromo da dieta $\mathrm{O}$ Zn tem sua absorção aumentada por vários ingredientes como a caseína, extrato de fígado, levedura seca, óleo de milho e farinha de sangue. A 
absorção do $\mathrm{Zn}$ é facilitada ainda pelo EDTA e outros agentes quelatantes, bem como pela vitamina $D$ e pela cisteína.

- Zn dos grãos e de fontes protéicas vegetais tem baixa disponibilidade, ao contrário das inúmeras fontes de proteína animal, incluindo o leite. Quando o carbonato e - lactato foram utilizados como fontes de $\mathrm{Zn}$, sinais de toxidez foram observados nos animais. Provavelmente, a absorção intestinal do $\mathrm{Zn}$ não depende apenas da interação intestinal com os níveis de ferro, cálcio e outros minerais da dieta (MoRes, 1993), mas também da forma do sal de $\mathrm{Zn}$. Desta maneira, os sais apresentam ampla variação na disponibilidade do $\mathrm{Zn}$ quando incluidos na dieta. Na forma de carbonato, sulfato, cloreto, nitrato e acetato, assim como o Zn metálico (HAHN E BAKER, 1993; MILIER ET AL., 1991) e o complexo Zn-metionina (WEDEKIND Eт AL.,1994), ele é altamente disponível, ao contrário das formas óxido, sulfeto (HAHN E BAKER, 1993; MILLER ET AL., 1991) e Zn-lisina (WEDEKIND ET AL., 1994) .

A absorção de $z n$ é afetada pelo seu próprio nível na dieta, ou seja, o percentual de absorção diminui com o aumento do nível na ração (MILIER ET AL., 1979). A idade e o sexo do animal também influenciam a absorção, sendo esta mais elevada em animais jovens e fêmeas.

No organismo, o Zn é carreado no plasma pela transferrina ao fígado sendo transportado pela albumina aos tecidos ou incorporado à globulina-a. A metalotioneína é a principal forma de armazenamento no fígado. Há evidências de que a enzima superóxido dismutase do fígado também armazena este mineral (MILLER ET AL., 1979). 
O Zn não absorvido da dieta e o das secreções gastrointestinal, pancreática e biliar, é excretado principalmente nas fezes (MILLER ET AL,, 1979), podendo se constituir num potencial poluidor ambiental (MOREs, 1993). Na realidade, elevados teores de metais pesados, tais como o zinco e o cobre, nos dejetos de suínos são causados pela adição desses elementos às rações (HARADA ET AL., 1993).

\subsection{Funções metabólicas do zinco}

o micromineral $\mathrm{Zn}$ atua no organismo como componente de diversas enzimas, incluindo desidrogenases, fosfatases, quinases, ribonucleases, carboxipeptidases e anidrase carbônica, e como componente da insulina. Portanto, o $\mathrm{Zn}$ influencia $\mathrm{O}$ metabolismo de proteínas, aminoácidos, ácidos nucléicos, carboidratos, lipidios e vitamina A. O Zn desempenha diversas funções tais como a acuidade no olfato e paladar, imunocompetência, crescimento, reprodução, lactação e stress (MIILER ET AL., 1979 E 1991; NRC, 1988).

De acordo com MiLLer ET AL. (1979), O $\mathrm{Zn}$ pode atuar de diversas formas: a) quando está localizado no sítio ativo da enzima, o Zn participa do processo catalítico; b) estabiliza a configuração da enzima; c) tem um papel regulatório da atividade enzimática; d) participa tanto do processo catalítico quanto da estabilização da molécula; e) participa tanto do processo catalítico quanto do processo regulatório da atividade da enzima. 
Em caso de deficiência de $\mathrm{Zn}$, doenças podem ser detectadas com a manifestação de diversos sintomas, tais como: paraqueratose, anorexia, crescimento lento, exaustão dos depósitos de gordura, atrofia serosa do tecido adiposo, atrofia do timo, diminuição na porcentagem de linfócitos, e queratinização da língua, esôfago e do cárdia do estômago (MILLER ET AI., 1991), e parto prolongado em porcas (KALINOWSKI E Chavez, 1984).

\subsection{Interações que afetam a absorção e o metabolismo do zinco}

O Zn interage com uma diversidade de elementos. Dentre as interações, o antagonismo entre cálcio e zinco é - mais antigo e bem documentado (FORBES, 1960, CITADO POR MILLER ET AL., 1979; LEWIS ET AL., 1957; LUECKE ET AL., 1957; Stevenson E EARLE, 1956;). Dietas com alto nível de cálcio aumentam significativamente a incidência e a severidade da deficiência de $\mathrm{Zn}$. Os fitatos podem exercer seus efeitos sobre a disponibilidade de $\mathrm{Zn}$ através da formação de um quelato ou de um complexo metálico de $\mathrm{Zn}$ que é altamente insolúvel no $\mathrm{pH}$ do intestino delgado. Desta forma, considera-se que elevadas concentrações de cálcio dietético exercem um efeito depressivo sobre a disponibilidade biológica do $\mathrm{Zn}$ somente na presença de fitatos, e assim este efeito é aumentado pelo alto nível de cálcio. Possivelmente estes 3 ions ( $\mathrm{Ca}, \mathrm{Zn}$, fitato) reagem formando um complexo mais insolúvel ou, no mínimo, menos absorvível do que apenas qualquer destes 2 minerais (O'DeLI ET AL., 1964). Também os fosfatos inorgânicos e o cálcio,

FORBES, R.M. NUTRICIONAL INTERACTION OF ZINC AND CALCIUM. Frd.Proc., 19: 643. 1961. 
quando em altos níveis na dieta, aumentam as exigências dos suínos em Zn (CABELL e EARLE, 1965). Altos níveis de cálcio em dietas de milho-farelo de soja resultam numa pobre absorção de Zn, uma vez que as elevadas concentrações de ácido fítico do milho e do farelo de soja formam o complexo CaZn-fitato no trato digestivo (MILLER ET AL., 1979 E 1991).

Outra interação também documentada é aquela existente entre o cobre e o zinco. A absorção de $\mathrm{z}$ é diminuída na presença do cobre e vice-versa (VAN CAMPEN, 1969), uma vez que estes elementos competem por um mesmo sistema de transporte no lúmen intestinal. Há evidências que uma interação zinco-cobre-cálcio afeta o crescimento dos animais e o armazenamento desses elementos no fígado (Bunch ET AL., 1963; Hoefer et AL., 1960; RItChIE et AL., 1963). Há evidências de que a suplementação de cobre ou cobre e zinco na ração eleva o nível de $\mathrm{Zn}$ no fígado (Bunch ET AL., 1963; RITChIE ET AL., 1963; SUTTLe E MILLS, 1966) e, portanto, O cobre suplementar poderia prevenir a paraqueratose provocada pela deficiência de Zn (BARBER ET AL., 1960; HoEfER ET AL., 1960; RITCHIE ET AL., 1963):

Por outro lado, o $\mathrm{Zn}$ suplementar na dieta resulta em abaixamento na concentração de cobre no fígado (BARBER ET AL., 1960), devido a uma diminuição na absorção de cobre e uma redução da concentração deste no plasma (UNDERWOOD, 1977). Assim, O Zn poderia estar relacionado com a diminuição do efeito tóxico do cobre quando administrado em altos níveis (HANRAHAN e O'GRADY, 1968; SHURSON, 1990).

A adição de chumbo às dietas diminui a retenção de Zn no fígado e nos rins. O excesso de $\mathrm{Zn}$ na dieta tende agravar a toxicidade do chumbo em suínos em crescimento (Hsu 
ET AL., 1975). UNDERWOOD (1977) também relatou uma competição entre $\mathrm{Zn}$ e cádmio pelos sítios de absorção do intestino. outras interações têm sido identificadas por diversos pesquisadores, como por exemplo, interações zinco-ferro (Cox e Hale, 1962; Settiemire e Matrone, 1967). Situações de deficiência de $\mathrm{Zn}$ resultam no aumento da absorção de cromo e a suplementação oral de Zn diminui a absorção do cromo e vice-versa (HAHN E Evans, 1975, CITADOS POR MILLER ET AL., 1979). JENSEN (1975), CITADO POR MILLER ET AL. (1979), demonstrou que altos níveis de zinco acarretaram sintomas de deficiência de selênio em frangos.

\subsection{Exigências dos suínos em zinco}

As exigências dos suínos em $\mathrm{Zn}$ são influenciadas por diversos fatores, incluindo os niveis de cálcio, cobre, cobalto, cádmio e EDTA da dieta, fitatos de plantas, nível e tipo de proteina e nível de histidina, assim como infecções intestinais (MILLER ET AL., 1979 E 1991; NRC, 1988).

As exigências de suínos desde o nascimento até o abate, alimentados com dietas à base de milho-farelo de soja, variam de 100 a 50 ppm (NRC, 1988). Porém, quando as dietas contém elevados níveis de cálcio, as exigências em Zn são aumentadas. As exigências são bem menores em dietas à base de caseína-glucose (em torno de $15 \mathrm{ppm}$ ) devido ao seu baixo conteúdo em fitatos (NRC, 1988; SHANKLIN ET AL., 1968; SмIтн Eт AL., 1962). Por outro lado, a recomendação é

HAHN, C.J. \& EWANS, G.W. ABSORPTION OF TRACE METALS IN THE ZINC-DEFICIENT RAT. AM. J. PHYSIOL., 228: 1020., 1975.

JENSEN, L.S. PRECIPATION OF A SELENIUM DEFICIENCY BY HIGH DIETARY LEVELS OF COPPER AND ZINC. PROC. SOC. EXPTL. BIOL. MED., 149: 113., 1975. 
mais alta para machos inteiros do que para leitoas, e mais alta para estas do que para machos castrados (LIPTRAP ET AL., 1970). Normalmente, as reservas de $\mathrm{Zn}$ prontamente utilizáveis dos alimentos são bem pequenas (NRC, 1980), sendo necessária a suplementação contínua deste mineral na dieta.

\subsection{Efeitos de altos níveis de zinco suplementar na} ração sobre o controle da diarréia pós-desmama.

A importância da alimentação no sistema de produção confinado representa cerca de $70 \%$ dos custos e, por isso, deve permitir a otimização do desempenho produtivo e reprodutivo. Com a intensificação da produção e o aumento do número de criações em confinamento, os ambientes criatórios tornaram-se mais contaminados. Portanto, deve-se também observar os efeitos da alimentação no controle e ou prevenção das doenças infecciosas e suas consequências.

Os problemas digestivos nos leitões na fase de creche aumentaram muito nos últimos anos, principalmente devido a intensificação da produção e a redução na idade da desmama (MOREs, 1993). As mudanças estruturais e ou bioquímicas que ocorrem no trato gastrointestinal resultam em alterações na função intestinal levando ao aparecimento de diarréias (BUDdLe e Bolton, 1992).

A incidência de diarréia e a baixa taxa de crescimento que ocorrem logo após a desmama são devidas a diversos fatores: temperatura, dieta, manejo e instalações inadequados. A bactéria Escherichia coli associada à 
diarréia em leitões recém-desmamados é um problema em muitas criações que praticam a desmama precoce (BERTOL E BRITO, 1993b; FRYER ET AI., 1992; HolM, 1990; MORES, 1993). A baixa digestibilidade das dietas e as reações imunológicas no epitélio intestinal a certos ingredientes, principalmente em dietas à base de milho-farelo de soja, favorecem o aparecimento dos problemas entéricos (BERTOL E BRITO, 1993B, 1995; KYRIAKIS, 1989). Baixo peso ao desmame e desuniformidade das leitegadas, contaminação da água e amplitudes térmicas diárias acima de $6{ }^{\circ} \mathrm{C}$ também predispõem - aparecimento de diarréia pós-desmama (BERToI E BRITo, 1995).

A "síndrome da má absorção" é causada pelo desmame e pela mudança na alimentação, o que leva a alterações digestivas, tais como o aumento na excreção de ácidos graxos e carboidratos nas fezes, fezes aquosas e alterações degenerativas na estrutura das vilosidades do intestino delgado (BERTOL E BRITO, 1995; KYRIAKIS, 1989). Tais alterações, associadas às do $\mathrm{pH}$ intestinal e o desequilíbrio do sistema imunológico do leitão favorecem a entrada e proliferação de agentes infecciosos e parasitários no intestino delgado do animal recémdesmamado, acarretando uma alta incidência de diarréia nesta fase (BERTOL E BRITO, 1995; KYRIAKIS, 1989).

Vários trabalhos têm demonstrado que a adição de altos níveis de Zn na ração, na forma de Zno, exerce um efeito benéfico na prevenção da diarréia, quando fornecida aos leitões por um período de 14 a 21 dias após a desmama (BerTOL E BRITo, 1992, 1993A, B, 1995; HOLM, 1990; LIMA ET AL., 1993A, B, 1994; MENTEN ET AL., 1992; MOREs, 1993). Os níveis de Zn recomendados variam de 1753 a 3000 ppm na forma de óxido de zinco. 
Suplementando 2500 ppm de zinco por duas semanas pós-desmama, Poulsen (1995) observou uma redução na incidência e severidade de diarréia não-específica. os efeitos benéficos da suplementação temporária de 2500 ou 4000 ppm de Zn na incidência da diarréia pós-desmama têm sido acompanhados por um aumento na atividade da fosfatase alcalina e na concentração plasmática de zinco. Este mesmo autor observou que a frequência da diarréia pós-desmama foi afetada pelo conteúdo de cálcio e cobre da dieta.

Efeitos profiláticos de uma dose de 2500 ppm de In foram significativamente maiores do que aqueles alcançados com 173 ppm de olaquindox (Holmgren, 1994). Não foi observada diarréia com o fim do fornecimento, revelando que $\circ$ Zn foi mais eficiente na prevenção da diarréia pósremoção, ou teve um efeito residual maior.

Ao contrário, FRYER ET AL. (1992), adicionando 3000 ppm de $\mathrm{Zn}$, por 21 dias, não observaram efeitos na severidade da diarréia apresentada por leitões recémdesmamados. SwINKELS ET AL. (1995) observaram uma maior incidência de diarréia severa em leitões arraçoados com uma dieta com alto teor de $\mathrm{Zn}$ quando comparada à ração controle com nível normal. Na realidade, esta maior incidência pode ser explicada pelo nível de $\mathrm{Zn}$ suplementado (250 ppm), muito abaixo dos niveis relatados por outros autores.

A maneira como o zinco atua no controle da diarréia causada por E. coli ainda é pouco conhecida. BrITo ET AL. (1993) demonstraram que o zinco é capaz de inibir o crescimento da bactéria "in vitro". Esses autores trabalharam com diferentes amostras de E. coli isoladas de casos de campo de diarréia pós-desmame. A tolerância das 
amostras de E. coli ao Zno foi variável, e assim foi determinada a concentração mínima inibitória do Zno para cada amostra. Isto em parte vem a explicar o fato de que em alguns rebanhos, mesmo com a adição de $\mathrm{Zn}$, pode ocorrer diarréia (MoRes, 1993). Embora o modo de ação do íon $\mathrm{Zn}$ sobre a bactéria não esteja completamente elucidado, há indicações de que o Zn atua na cadeia respiratória da $E$. coli, por inibição do transporte ativo de açúcares e aminoácidos (Kasahara e AnRaku, 1972 E 1974).

\subsection{Efeitos de altos níveis de zinco suplementar na}

\section{ração sobre o desempenho dos suínos.}

o Zn é um mineral essencial para o bom desempenho e saúde dos suínos. É indispensável para um grande número de funções, desde a regulação ácido-base até imunocompetência, componente e ativador de enzimas Zndependentes. O nível normal de $\mathrm{Zn}$ em dietas de suínos varia de 50 a $100 \mathrm{ppm}$, de acordo com a idade e o estágio fisiológico do animal (MILLER ET AL., 1991; NRC, 1988), o tipo de dieta e a fonte de zinco (FRYER ET AL., 1992; NRC, 1988).

Nos últimos anos, várias pesquisas têm evidenciado que a suplementação da dieta entre 14 e 28 dias pós-desmame de leitões com níveis supra-nutricionais de $\mathrm{Zn}$ (1500 - $4000 \mathrm{ppm})$ resulta em melhora no desmpenho dos animais, pela redução da severidade e incidência de diarréia e a taxa de mortalidade (BERTOL E BRITo, 1993A, B, 1995; HALI, 1992; HOLM, 1990; LIMA ET AI., 1993A, B, 1994; MENTEN et AL., 1992; MIYADA ET AL., 1993, 1994). A partir desses estudos, observaram-se melhoras no ganho de peso, consumo 
de ração e conversão alimentar na ordem de $20 \%$, $14 \%$ e $7 \%$, respectivamente, para suínos na fase de creche.

Por outro lado, o desempenho foi piorado quando um nível de 4000 ppm de $\mathrm{Zn}$, como $\mathrm{ZnO}$, foi suplementado à dieta de leitões recém-desmamados (COX E HALE, 1977; HSU ET AL., 1975). Quando $3200 \mathrm{ppm}$ e $2400 \mathrm{ppm}$ de $\mathrm{Zn}$ foram suplementados, o ganho diário de peso dos leitões foi aumentado, mas maior quantidade de alimento foi requerida por quilograma de ganho (Hotm, 1990). FRYER ET AL. (1992) não observou efeitos benéficos de $3000 \mathrm{ppm}$ de $\mathrm{Zn}$ sobre as taxas de ganho de peso ou eficiência alimentar.

Grande parte dos trabalhos realizados foi desenvolvida com o objetivo de se determinar qual o nível mais adequado de $\mathrm{Zn}$ como promotor do crescimento. os níveis testados variaram de $250 \mathrm{ppm}$ a $8000 \mathrm{ppm}$ (BERTOL E BRITO, 1993A; BRINK ET AL., 1959; LIMA ET AL., 1993B; MIYADA ET AL., 1993, 1994). Os níveis entre 1500 e $3000 \mathrm{ppm}$ foram os mais eficientes em melhorar os parâmetros ganho diário de peso, consumo diário de ração e conversão alimentar (BERTOL E BRITo, 1993A; LIMA ET AL., 1993B; MIYADA ET AL., 1993, 1994).

O período ideal de fornecimento de $\mathrm{Zn}$ também tem sido estudado (BERTOL E BRITO, 1993B; LIMA ET AL., 1993A, 1994; MIYADA ET AI., 1996). Alguns trabalhos têm demonstrado benefícios da utilização de altos níveis de zinco por 14 a 21 dias pós-desmama (HoLM, 1990; MENTEN ET AL., 1992) sobre O desempenho e controle de diarréia. Por outro lado, há relatos de toxidez com o uso de dietas contendo $2000 \mathrm{ppm}$ deste micromineral durante períodos de 6 a 7 semanas (BRINK ET AL., 1959; COX E HALE, 1962). BeRtol E BRIto (1992 e 1995), fornecendo uma dieta com $3000 \mathrm{ppm}$ de zinco, dos 0 aos 21 
dias pós-desmama, observaram 12,5 \% de mortalidade por doença do edema após a remoção do óxido de zinco da dieta.

Para LIMA ET AL. (1993A e 1994), a suplementação de $2400 \mathrm{ppm}$ de $\mathrm{Zn}$ foi eficiente na melhora do desempenho e na prevenção da diarréia pós-desmame de leitões desmamados com 29 dias de idade, sendo que o período de suplementação mais adequado foi até 14 dias pós-desmame em relação ao período até 21 dias. BERTOL E BRITO (1993B) compararam as sequencias 0-0, 3000-0, 3000-1500 e 3000-3000 ppm de zinco nas dietas fornecidas de 1 a 21 e de 22 a 42 dias pós-desmama, respectivamente. Não foram observados sinais clínicos de toxidez em nenhum dos tratamentos, embora possa ter ocorrido toxidez subclínica na sequência 3000-3000, já que o desempenho dos animais foi piorado em relação à sequência 3000-1500. A melhor combinação de níveis foi 3000-1500 ppm. A sequência 3000-0 apresentou 8,7 \% mortalidade por doença do edema após a retirada do $\mathrm{Zn}$ da dieta. Estes autores concluíram ainda que o fornecimento de $3000 \mathrm{ppm}$ de Zn de 1 até 21 dias pós-desmame proporcionou redução na incidência de diarréia e melhora no desempenho. A sequência 3000-1500 ppm de $\mathrm{Zn}$ na dieta proporcionou melhora no desempenho e redução na mortalidade por doença do edema em leitões.

Estes níveis de suplementação de $\mathrm{Zn}$ excedem em muito àqueles exigidos pelos suínos jovens (BRINK ET AL., 1959; NRC, 1988). Entretanto, outros estudos têm relatado sinais de toxidez com a utilização de dietas contendo 2000 ppm de Zn ou mais (BRINK ET AL., 1959; COX E HALE, 1962; LIMA ET AL., 1993B; MIYADA ET AL., 1994). A toxidez parece ser dependente da fonte utilizada. Esses niveis de $\mathrm{Zn}$ podem 
provocar toxidez em suínos, embora esta pareça não ocorrer ou ser menos severa quando o Zno é a fonte utilizada para suplementação. A baixa disponibilidade do $\mathrm{Zn}$ do óxido comparada à outras fontes pode explicar a sua maior tolerância pelos suínos (HAHN E BAKER, 1993). As concentrações plasmáticas de $\mathrm{zn}$ e a atividade da enzima fosfatase alcalina, que é $\mathrm{Zn}$-dependente, foram aumentadas quando níveis suplementares de $\mathrm{Zn}$ (4000 e 5000 ppm) foram incorporados às rações de leitões pós-desmame (HILL ET AL., 1983; HSU ET AL., 1975).

\subsection{Modos de ação do zinco como promotor do crescimento}

Evidências da promoção do crescimento pela ação antibacteriana têm sido acumuladas durante anos através da descoberta de um grande número de agentes que influenciam o crescimento de microrganismos ou a produção de seus produtos metabólicos. Esses compostos variam enormemente na sua estrutura química, tais como: arsenicais, nitrofuranos, sulfonamidas, quinoxalinas, antibióticos e sais inorgânicos (sulfato de cobre, p.ex.). Até o experimento de Holm (1990), em nenhum dos trabalhos em que se utilizaram altos niveis de $\mathrm{Zn}$ houve qualquer evidência de um efeito do micromineral como protetor ou promotor de crescimento.

Os agentes antimicrobianos estimulantes do crescimento são utilizados com o objetivo de reduzir os prejuizos causados pelos distúrbios entéricos. Estes têm sido associados, principalmente, às alterações no equilibrio das espécies microbianas do intestino delgado ou no metabolismo dos microorganismos intestinais (VISEK, 1978; 
Bertol E BRITO, 1995). Segundo WALIACE (1970), os aditivos usados como promotores de crescimento têm a característica comum de impedir ou suprimir o crescimento de microorganismos no trato gastrointestinal. Segundo BRITO ET AL. (1993) o mecanismo pelo qual o óxido de $\mathrm{Zn}$ atua permanece desconhecido. Entretanto, estes autores comprovaram que $\circ$ Zno exerce ação bactericida e ou bacteriostática sobre amostras de $E$. coli. $O \mathrm{Zn}$ possivelmente possui o mesmo mecanismo de ação dos agentes antibacterianos na sua atividade de promoção do crescimento. O modo de ação que determina melhoras no desempenho dos animais não é um processo simples, único. As principais teorias propõem: a) efeito metabólico; b) efeito sobre a economia de nutrientes; c) depressão na formação de toxinas e; d) controle de doenças (VISEK, 1978; WALIACE, 1970).

Para WALLACE (1970), o efeito metabólico poderia ser responsável pela atividade bacteriana e ou bacteriostática dos antibióticos e outros aditivos. Não se sabe, porém, se os sistemas enzimáticos do hospedeiro ou os da microflora são os mais envolvidos. Os baixos níveis dos aditivos nas rações e a absorção limitada da maioria praticamente descarta a opção de um efeito metabólico direto sobre os tecidos do animal hospedeiro. Os efeitos favoráveis no desempenho animal são devidos muito provavelmente a um efeito direto no metabolismo das populações microbianas do trato digestivo.

Com relação ao efeito na economia de nutrientes, sabe-se que a microflora intestinal sintetiza certos aminoácidos e vitaminas. É também sabido que os microorganismos competem com o hospedeiro pelos nutrientes 
disponíveis. A adição de agentes antibacterianos às rações causam um aumento na população de certos coliformes intestinais e leveduras. Esses organismos são conhecidos por sintetizar nutrientes essenciais para 0 animal. Portanto, em casos de deficiência nutricional, um aditivo poderia melhorar o desempenho de um animal pela estimulação na sintese microbiana de um nutriente (WALIACE, 1970).

Outros organismos que competem com 0 hospedeiro por nutrientes são inibidos por determinados compostos. Os antibacterianos que são mais efetivos na redução do número destes organismos também são os mais efetivos como promotores de crescimento (KELLOG ET AL., 1966). As exigências protéicas que maximizam o desempenho de suínos podem ser mais baixas na presença de antimicrobianos (WALLACE, 1970).

o aumento na absorção intestinal pode ser outra via para a economia de nutrientes. Os antibióticos destroem ou inibem os organismos que causam danos à parede. Isto implica na diminuição da espessura da parede intestinal dos animais alimentados com rações contendo aditivos antimicrobianos, tornando mais rápida e mais fácil a absorção no intestino (WALLACE, 1970). Resumindo, o modo de ação dos antimicrobianos pela economia de nutrientes pode ser manifestado pela estimulação do crescimento de microrganismos sintetizadores de nutrientes, pela inibição dos microrganismos competidores por nutrientes e pelo aumento na absorção intestinal.

Os agentes promotores de crescimento reduzem a produção microbiana de toxinas prejudiciais ao desenvolvimento do animal, tal como a amônia (VISEK, 1978). 
o próprio tecido animal produz amônia, produto final da degradação de substâncias nitrogenadas (proteínas, aminoácidos). As bactérias agem sobre essas mesmas substâncias no lúmen do intestino, tornando-se a principal fonte de amônia fora dos tecidos. Desta maneira, a diminuição na produção de amônia bacteriana está relacionada ao efeito promotor de crescimento dos agentes antibacterianos. Esta toxina diminui a longevidade das células epiteliais, exigindo uma maior taxa de reposição de células. Portanto, esses aditivos criam uma menor necessidade de reposição das células do epitélio intestinal e, como consequência, um menor gasto de nutrientes para a reposição que serão desviados para o crescimento animal.

De acordo com WALIACE (1970), os principais benefícios da utilização dos antimicrobianos resulta na supressão ou controle de doenças subclínicas ou não especificas. Animais saudáveis, criados em ambientes sempre limpos, livres de germes, esterelizados, respondem com menor intensidade aos antibacterianos. As respostas aos aditivos antimicrobianos são maiores num ambiente contaminado.

Os antibióticos e outros aditivos têm contribuido enormemente para a sobrevivência e para o crescimento dos animais. A resposta aos antimicrobianos sobre o desempenho é maior nos animais mais jovens (WALLACE, 1970), nos que consomem dietas desbalanceadas ou que estejam em condições de estresse (VISEK, 1978).

Mais recentemente, STAHLY (1995) propôs outro modo de ação para os agentes antimicrobianos. Os antibacterianos têm sua ação documentada sobre uma 
variedade de antígenos. A eficácia destes agentes nos animais depende: 1 ) do tipo e localização do antígeno no trato gastrointestinal; 2) da sua ação fisiológica e características de absorção $e ; 3$ ) do sistema imunológico do hospedeiro. A ingestão de agentes antimicrobianos têm determinado uma redução dos níveis de citoquininas circulante em frangos. As citoquininas são compostos com ação hormonal liberados pela ativação das células imunológicas. Estes compostos liberados alteram os processos metabólicos no animal. Especificamente, essas citoquininas diminuem o consumo voluntário de ração, elevam a temperatura corporal, estimulam a liberação de hormônios catabólicos (ACTH, tiroxina, p.ex.) e inibem a atividade de hormônios anabólicos (peptídeos e pST, p. ex.) e modificadores metabólicos (IGF-I, p.ex.).

Além disso, as células musculares de suínos alimentados com certos antibacterianos têm mostrado "in vitro" um crescimento aumentado e uma degradação reduzida de proteína muscular (HATHAWAY ET AL., 1990). Este resultado é devido a uma redução na produção de um fator inibitório e/ ou num aumento da produção de um fator promotor de crescimento devido à habilidade do antimicrobiano em modificar e/ou auxiliar na eliminação de um antígeno, minimizando, desta forma, a ativação do sistema imunológico do animal. Teoricamente, isto pode ocorrer via redução na liberação de compostos catabólicos (ACTH, tiroxina, p.ex.) e ou aumento na atividade de compostos anabólicos (IGF-I). Baseado nestas relações, os agentes antimicrobianos que tiveram sucesso na modificação e ou eliminação dos antígenos do animal mostraram uma alteração na musculatura corporal, tanto quanto na taxa e eficiência de crescimento. 


\subsection{Impacto ambiental causado pelo zinco nos dejetos de suínos}

Até a década de 70, os dejetos de suínos não constituiam um fator preocupante em termos de poluição ambiental no Brasil, devido à pequena concentração de animais, bem como os solos agrícolas tinham capacidade de absorvê-los ou aproveitá-los como adubo orgânico. Com o desenvolvimento da suinocultura e a produção de grandes quantidades de dejetos sem tratamento adequado, estes se tornaram a maior fonte poluidora dos mananciais de água de Santa Catarina (OLIVEIRA, 1994).

Os dejetos de suínos podem apresentar grandes variações nos seus componentes, dependendo do sistema de manejo adotado, da composição da ração fornecida aos animais e, principalmente da quantidade de água em sua composição. Esses dejetos têm grande potencial para melhoria das propriedades químicas do solo e disponibilidade de nutrientes para as plantas desde que adequadamente utilizados, visando a preservação do ambiente (OLIVEIRA, 1994).

Segundo SIQUEIRA ET AL. (1987), citado por OLIVEIRA (1994), valores acima de 0,50 ppm de $\mathrm{Zn}$ são limitantes para sua utilização nas condições dos solos do Rio Grande do Sul e Santa Catarina. Valores acima poderiam ocasionar baixa produtividade em algumas culturas comprometendo seu uso como fertilizante.

Na Holanda, $250 \mathrm{ppm}$ é o nível máximo de Zn SIQUEIRA, C.J.F. ET AL. RECOMENDAÇõES DE ADUBAÇÃo E CALAGEM PARA OS ESTADOS DO RIO Grande do SUl E SaNTA CATARINA. EMBRAPA-CNPT, 1987. 100P. 
(1996) recomenda evitar a utilização de altos níveis de Zno como promotor de crescimento e no controle de diarréia, já que a maior parte do $\mathrm{Zn}$ ingerido é eliminado nas fezes. Leitôes alimentados com rações contendo $4000 \mathrm{ppm}$ de Zno, por 3 a 5 semanas, excretam até $17500 \mathrm{mg}$ de $\mathrm{Zn}$ por $\mathrm{kg}$ de fezes (MOREs, 1993). LIMA (1996) é a favor de medidas alernativas para $\circ$ controle da poluição ambiental causada pelos dejetos, tais como a utilização de enzimas na dieta dos leitões, melhorar as condições de higiene das instalações.

\section{MATERIAL E MÉTODOS}

O experimento foi conduzido em uma instalação de creche do Setor de Suinocultura do Departamento de Zootecnia, da Escola Superior de Agricultura "Luiz de Queiroz", Universidade de São Paulo, em Piracicaba-SP, no período de junho a dezembro de 1994. A instalação contava com 20 gaiolas metálicas suspensas, de piso semi-ripado, com 1,50 $\mathrm{X} 1,20 \mathrm{~m}$, equipadas com comedouros semi-automáticos, bebedouros tipo "chupeta" e lâmpadas infra-vermelho de aquecimento de 250 W. As instalações eram manejadas com fluxo contínuo de animais.

Foram utilizados 150 leitões, machos castrados e fêmeas, puros ou cruzados, das raças Landrace, Large White e Duroc, desmamados aos 28 dias de idade média, com peso médio inicial de $6,85 \mathrm{~kg}$. Os tratamentos foram: 0 , $750,1500,2250$ e $3000 \mathrm{ppm}$ de $\mathrm{Zn}$ (na forma de Żno). 
Foi utilizado um delineamento experimental em blocos casualizados, com 8 repetições por tratamento, sendo 6 blocos com 4 e 2 com 3 animais por unidade experimental, de acordo com a leitegada de origem, sexo e peso inicial.

A composição percentual da ração basal é apresentada na Tabela 1. A ração foi formulada de acordo com as recomendações do NRC (1988) e RostAgno ET AL. (1983).

A ração e água foram fornecidas à vontade durante todo o período experimental de 28 dias. Semanalmente, os animais eram pesados e o consumo de ração dos leitões de cada baia era anotado a fim de se calcular a conversão alimentar.

Ao final do experimento foram coletadas amostras de sangue de 2 animais por unidade experimental que representavam a média da baia, após um jejum de 5 horas. As amostras de sangue foram coletadas da veia cava anterior dos leitões, em seringas de $10 \mathrm{ml}$ lavadas com EDTA $10 \%$ e transferidas para tubos de ensaio com 0,1 ml de EDTA $10 \%$. Cada amostra foi dividida em duas sub-amostras que foram mantidas em caixa de isopor com gelo para posterior manuseio em laboratório.

O plasma foi obtido pela centrifugação de uma das subamostras de sangue a $3000 \times \mathrm{g}$ por 15 minutos. Em seguida, foram preparadas amostras compostas ("pool") com volumes equivalentes de plasma de cada animal, a fim de que cada uma representasse os animais de uma baia.

As amostras de sangue e plasma eram, então, enviadas ao laboratório*, para o procedimento das análises dos

*Laboratório Prevlab - Centro de Patologia Clínica Preventiva Ltda. Piracicaba - SP 
componentes. A hemoglobina foi determinada pelo método de cianometahemoglobina e o hematócrito pelo método de microcentrifugação. As frações proteína total, albumina e uréia do plasma foram determinadas pelos métodos do biureto automatizado, B.C.G. e urease, respectivamente.

Os dados de desempenho e dos componentes sanguíneos e plasmáticos foram submetidos à análise de variância utilizando-se dos programas SANEST - Sistema de Análise Estatística (Zonta, 1983) para as variáveis ganho diário de peso e consumo diário de ração e GLM (SAS, 1985) para a variável conversão alimentar. Foi feita a decomposição dos graus de liberdade em seus componentes de regressão (Iinear, quadrático, cúbico $e$ de $4^{\circ}$ grau) através de polinômios ortogonais.

\section{RESULTADOS E DISCUSSÃO}

\subsection{Características de desempenho}

Através das pesagens semanais de cada animal e do registro do consumo de ração do grupo de animais, de cada baia, foram obtidos os resultados das características de desempenho: ganho diário de peso (GDP), consumo diário de. ração (CDR) e conversão alimentar (CA), conforme as Tabelas 2 e 4. Os valores originais dos parâmetros de desempenho, para cada período de suplementação de zinco estão presentes nas Tabelas A1, A2, A3 e A5 do Apêndice. 
Tabela 1 - Composição percentual da ração basal.

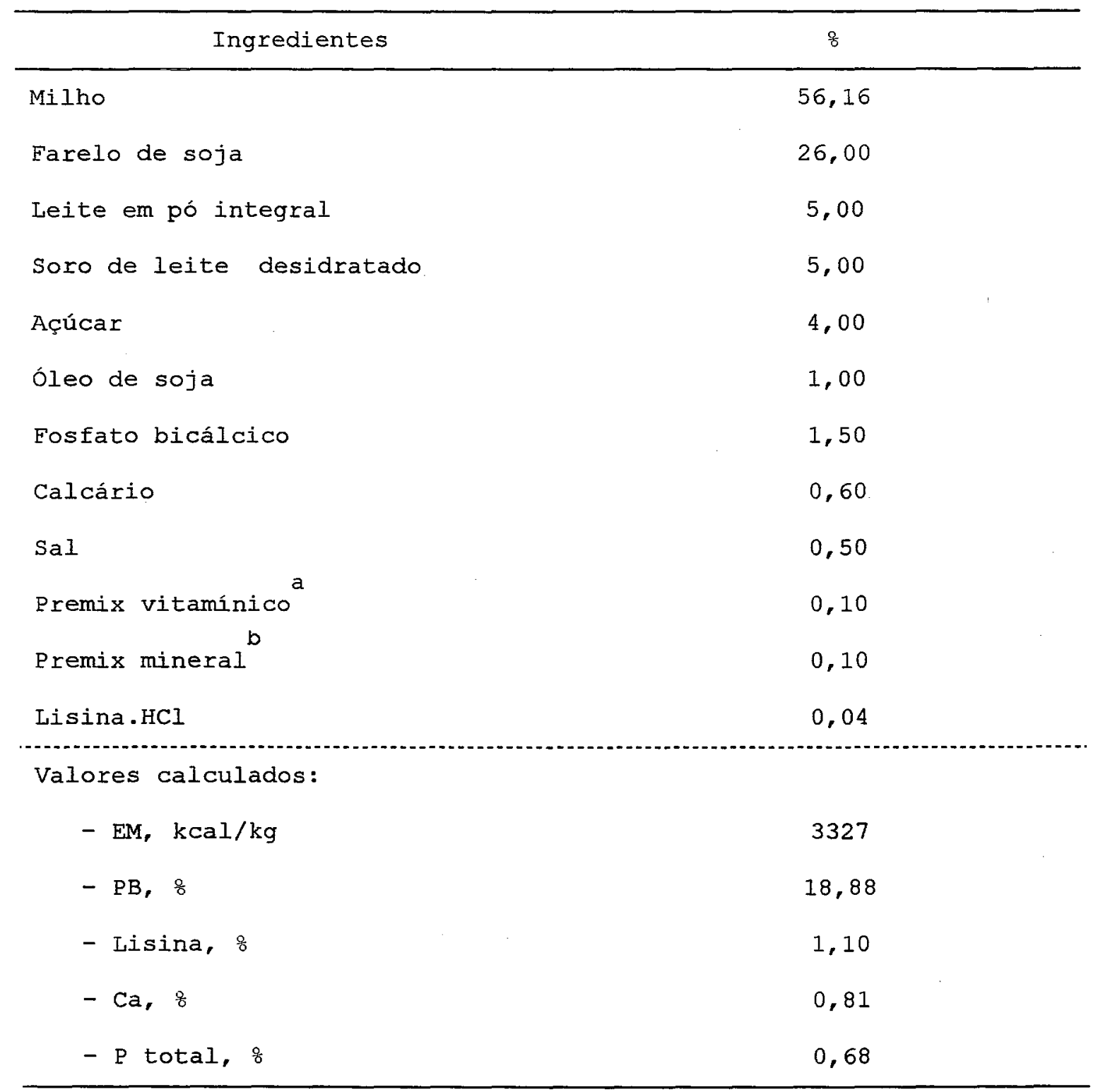

${ }^{a}$ Suprindo as seguintes quantidades por $\mathrm{kg}$ de ração: Vit. A, 8000 UI; vit. D3, 500 UI; vit. E, $18 \mathrm{mg}$; vit. $\mathrm{K}_{3}, 2 \mathrm{mg}$; tiamina, 1,5 mg; riboflavina, $4 \mathrm{mg}$; piridoxina, 1,5 mg; vit. $\mathrm{B}_{12}, 18 \mathrm{mcg}$; ác. fólico, $400 \mathrm{mcg}$; biotina, $100 \mathrm{mcg}$; pantotenato de Ca, $15 \mathrm{mg}$; niacina, $30 \mathrm{mg}$; Se, $120 \mathrm{mcg}$.

${ }^{\mathrm{b}}$ Suprindo as seguintes quantidades por $\mathrm{kg}$ de ração: $\mathrm{Fe}, 88 \mathrm{mg}$; Cu, $15 \mathrm{mg} ; \mathrm{zn}, 80 \mathrm{mg} ; \mathrm{Mn}$, $45 \mathrm{mg}$; $\mathrm{I}, 1 \mathrm{mg}$. 
Durante a primeira semana do experimento, o $\mathrm{Zn}$ suplementar da dieta exerceu efeitos lineares no GDP $(P<0,00006)$, no $\operatorname{CDR} \quad(P<0,0002)$ e na $C A \quad(P<0,04)$. As equações que descrevem estas respostas são fornecidas na Tabela 4 e ilustradas na Figura 1. MIYADA ET AL. (1993) observaram efeitos quadráticos para o GDP e CDR utilizando os mesmos níveis de $\mathrm{Zn}$ do presente trabalho. De forma semelhante, a CA apresentou um comportamento linear.

No presente experimento, houve uma melhora de até $166^{\circ}$ no GDP, 30,4\% no $C D R$ e 19,1\% na CA para 0 nível mais elevado do mineral suplementado na ração. Nenhum autor comenta os resultados obtidos no desempenho dos animais na primeira semana pós-desmame. Segundo MENTEN ET AL. (1992), não se toma a primeira semana isoladamente porque aí ocorre grande variação, muitas vezes não sendo consequência dos próprios tratamentos. Os coeficientes de variação para GDP $(39,41 \%)$ e para CA $(25,38 \%)$ são altos, mas apesar disto as respostas devidas aos tratamentos foram altamente significativas.

Nas duas primeiras semanas de experimentação, a adição de altos níveis de $Z n$ à ração dos leitões proporcionou uma resposta linear no GDP ( $P<0,00001)$, no $C D R$ $(P<0,00001)$ e na $C A(P<0,0005)$. As equações que descrevem estas respostas podem ser encontradas na Tabela 3 e ilustradas na Figura 2. Estas respostas são concordantes com as respostas obtidas por MIYADA ET AI. (1994). MIYADA ET AL. (1993) observaram efeitos lineares semelhantes para O GDP e CA, enquanto observaram um efeito quadrático para o CDR nestas duas primeiras semanas. LIMA ET AL. (1993A) observaram respostas quadráticas aos níveis de $\mathrm{Zn}$ para 0 GDP e CDR, havendo um aumento para ambos os parâmetros até 
- nível de $2400 \mathrm{ppm}$ de $\mathrm{Zn}$. Contudo, com o nível mais alto de $\mathrm{Zn}$ (3200 ppm), houve um efeito depressivo, sugerindo que este pode ter causado toxidez nos animais.

O aumento no GDP de até $86,2 \%$ proporcionado pela adição de $\operatorname{Zn}$ foi consequência do aumento no $\operatorname{CDR}(36,3 \%)$ e da melhora na CA $(26,7 \%)$. Diante desta melhora, pode-se sugerir um maior aproveitamento dos nutrientes da ração pelos animais recebendo Zn suplementar. MENTEN ET AL. (1992), LIMA ET AL. (1993A, B, 1994), MIYADA ET AL. (1993, 1994), também observaram efeitos benéficos dos elevados niveis de Zn na ração sobre a performance dos leitões. Os melhores resultados encontrados no tratamento com $3000 \mathrm{ppm}$ de $\mathrm{Zn}$ nas duas primeiras semanas também foram observados por MIYADA ET AL. (1993, 1994, 1996), MENTEN ET AL. (1992), FRYER ET AL. (1992), enquanto que HoLM (1990) E LIMA ET AL. (1993A, B, 1994) determinaram que 0 melhor resultado no GDP foi conseguido com a suplementação de 2400 ppm de Zn.

Para as três primeiras semanas, os resultados são apresentados na Tabela 2. As equações que descrevem as respostas dos animais do $1^{\text {으 }}$ ao $21^{\circ}$ dia de experimentação são apresentadas na Tabela 3, enquanto que as ilustrações aparecem na Figura 3. O $\mathrm{Zn}$ suplementar na ração proporcionou respostas lineares no GDP $(P<0,00001)$, na $C A$ $(P<0,003)$ e respostas linear $(P<0,00001)$ e cúbica $(P<0,03)$ no $\mathrm{CDR}$.

Nestas três primeiras semanas do experimento, as respostas dos animais ao $\mathrm{Zn}$ suplementar referente ao GDP, $\mathrm{CDR}$ e CA foram melhoradas, respectivamente, em 47,8\%, $34,6 \%$ e $12,6 \%$. As melhores respostas para o GDP e CDR 

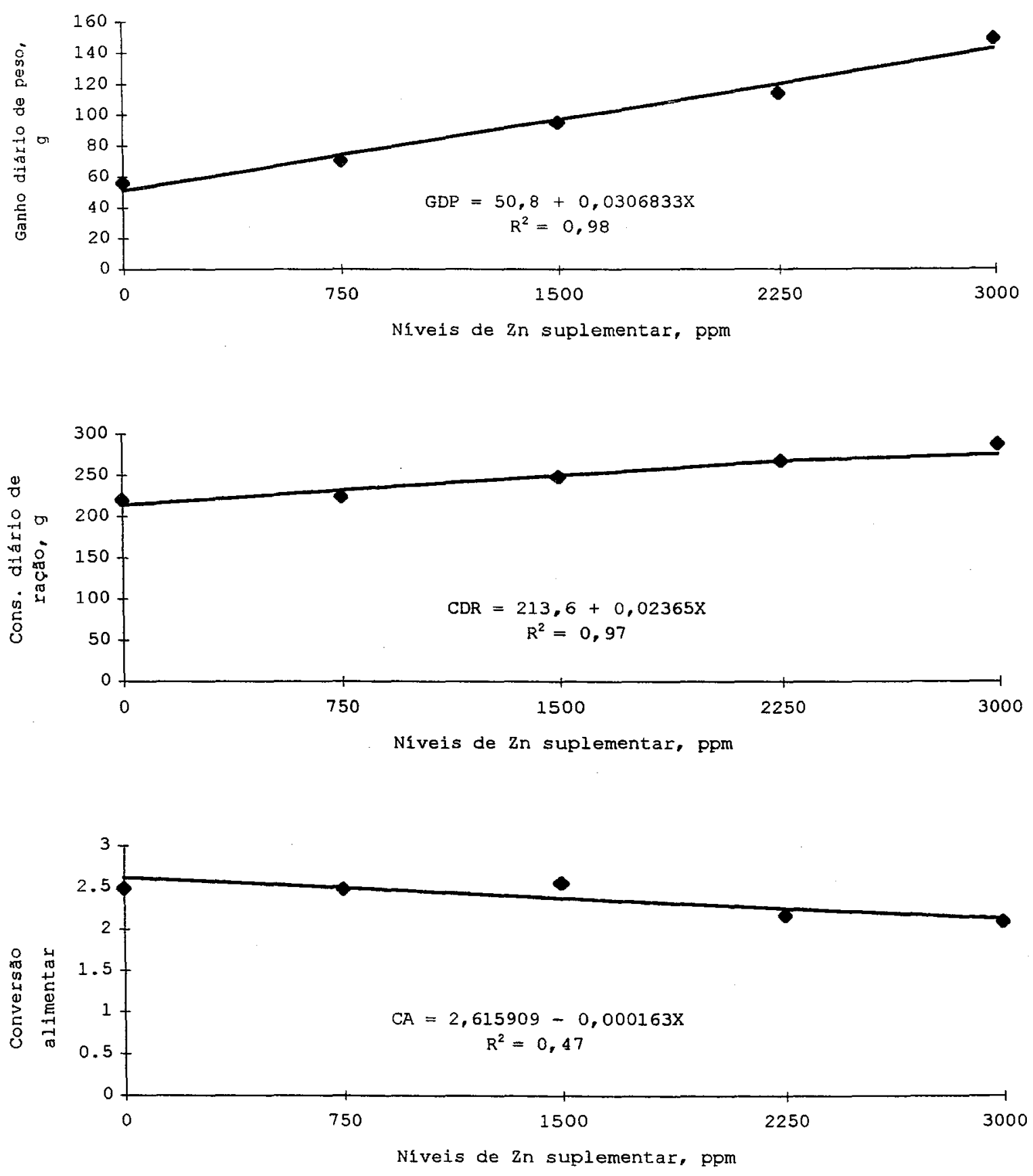

Figura 1. Efeitos dos niveis de $\mathrm{Zn}$ sobre o ganho diário de peso (GDP, g), consumo diário de ração (CDR, g) e conversão alimentar (CA) de leitões em recria na primeira semana de experimentação. 
foram obtidas com o maior nível de suplementação de Zn. BERTOL E BRITO (1995) observaram respostas favoráveis à suplementação de $3000 \mathrm{ppm}$ de $\mathrm{Zn}$ em relação ao controle com $250 \mathrm{ppm}$ de cobre $\left(\mathrm{CuSO}_{4}\right)$.

As respostas dos animais para as semanas 3 e 4 do presente experimento são encontradas na Tabela 2. O Zn suplementar proporcionou respostas linear $(P<0,0001)$ e cúbica $(P<0,0007)$ para $O$ GDP e também linear $(P<0,00001)$ e cúbica $(P<0,001)$ para $\circ$ CDR. $A \quad C A$ apresentou um comportamento linear $(P<0,0007)$. As equações que representam essas respostas podem ser observadas na Tabela 3 e ilustradas na Figura 4. Nenhum trabalho anterior analisou apenas as semanas 3 e 4 de experimentação. A partir da terceira semana, o melhor nível de inclusão de $\mathrm{Zn}$ passou a ser 2250 ppm, para o GDP e para o CDR, ao mesmo tempo que o nível de 3000 ppm apresentou uma redução no seu efeito benéfico. Em relação ao GDP, a resposta dos leitões ao nível mais alto de $\mathrm{Zn}$ foi $11 \%$ inferior àquela obtida com - nível de 2250 ppm (513 X 573 g, respectivamente), e este $24 \%$ superior ao controle (573 X 460 g). De maneira semelhante, O CDR e a CA também foram afetados. Portanto, o efeito negativo provocado por $3000 \mathrm{ppm}$ de $\mathrm{Zn}$, quando fornecida por mais de duas semanas, pode ser um possível efeito tóxico do mineral à partir da terceira semana pósdesmama.

Considerando o período total de experimentação, as respostas dos animais podem ser observadas na Tabela 2. As equações e figuras que ilustram as respostas são apresentadas na Tabela 3 e na Figura 5. As respostas a adição do $\mathrm{Zn}$ às rações dos leitões proporcionaram 

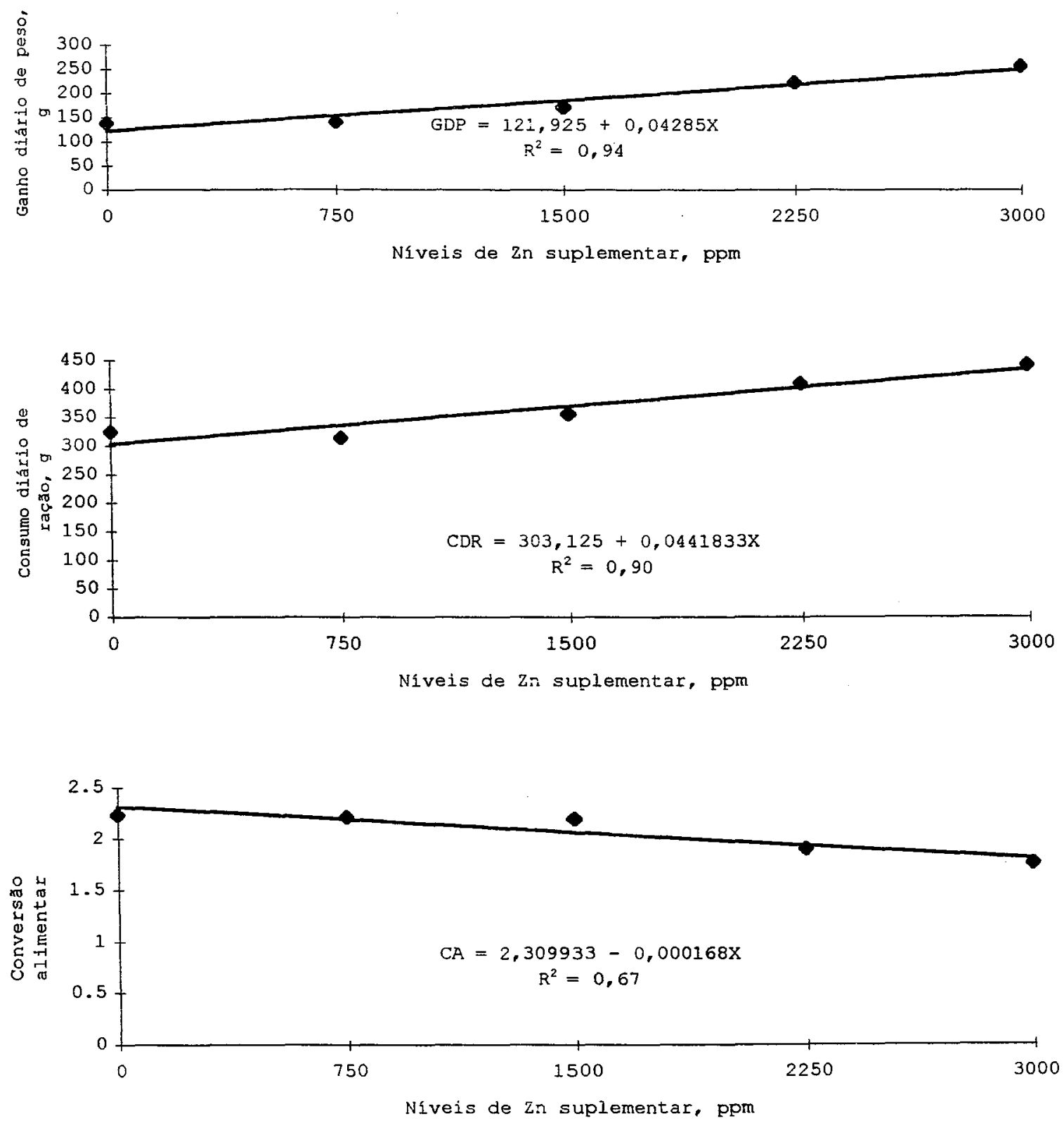

Figura 2. Efeitos dos níveis de $\mathrm{Zn}$ sobre o ganho diário de peso (GDP, g), consumo diário de ração (CDR, g) e conversão alimentar (CA) de leitões em recria nas duas primeiras semanas de experimentação. 
respostas: Iinear e cúbica para $0 \operatorname{GDP}(P<0,00001$ e $P<0,004)$ e para o $\operatorname{CDR}(\mathrm{P}<0,00001$ e $\mathrm{P}<0,003)$, sem contudo influenciar a CA $(P>0,05)$ dos animais. MIYADA ET AL. (1993), utilizando os mesmos níveis apenas nas duas primeiras semanas, observaram resposta linear para o GDP e para o CDR e para a CA. Num outro experimento, fornecendo rações com os mesmos níveis de Zn durante as 4 semanas, MIYADA ET AL. (1994) verificaram respostas quadrática para o GDP e para a CA, enquanto que para $\mathrm{O} C \mathrm{CD}$ a resposta apresentada foi linearmente positiva. Por outro lado, com a adição de 2400 ppm de Zn, LIMA ET AI. (1993A) obtiveram respostas quadráticas para o GDP e CDR.

No presente experimento, os aumentos proporcionados pela adição do mineral às rações foram de $33,1 \%$ no GDP e 28,3\% no CDR. Apesar de não significativa, houve uma melhora de 4,7\% na CA. Entretanto, essas respostas foram observadas com o nível de $2250 \mathrm{ppm}$ de $\mathrm{Zn}$ suplementado à dieta. Este aumento no GDP foi devido principalmente ao maior consumo de ração já que a CA para o período total foi semelhante entre todos os tratamentos.

Embora nas três primeiras semanas o nivel de 3000 ppm de $\mathrm{Zn}$ tenha determinado melhoras na performance, quando se considerou o período total, observou-se um efeito depressivo no desempenho dos animais, indicando que o uso continuado de 3000 ppm de Zn, além das três semanas pósdemame, pode ser tóxico aos animais. Num trabalho anterior, MIYADA ET AL. (1994) relataram que até 2250 ppm de Zn, o desempenho dos leitões foi sensivelmente melhorada em quaisquer períodos. Contudo, após a terceira semana, houve uma piora na performance dos animais recebendo 3000 

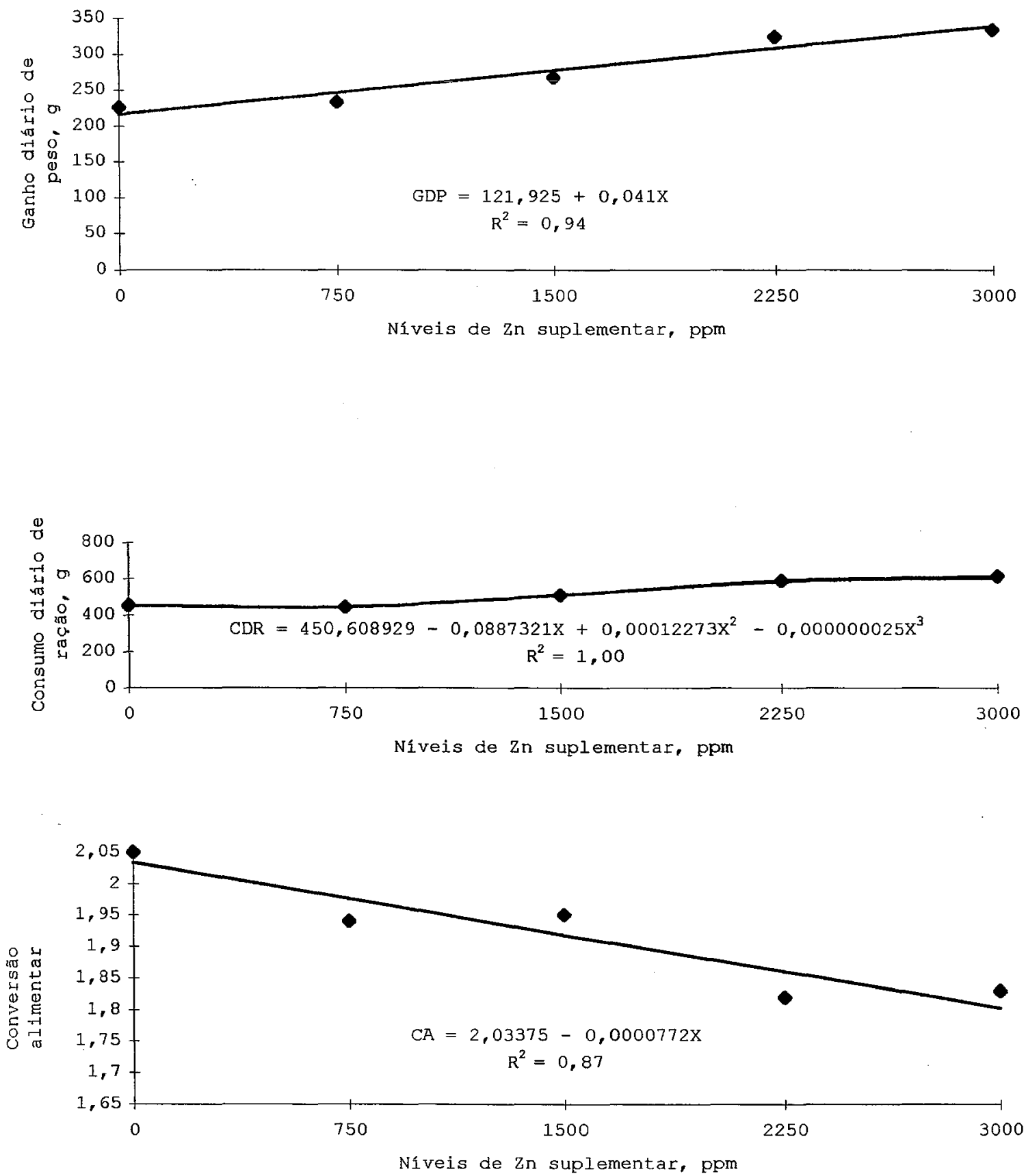

Figura 3. Efeitos dos níveis de $\mathrm{Zn}$ sobre o ganho diário de peso (GDP, g), consumo diário de ração (CDR, g) e conversão alimentar (CA) de leitões em recria nas três primeiras semanas de experimentação. 
ppm, que pode ser um indicativo de um possivel efeito tóxico deste alto nível.

Segundo Schell e Kornegay (1996), o modo de ação de altos níveis de $\mathrm{Zn}$, como promotor do crescimento, é através da redução das diarréias. Isto pode explicar a ausência de respostas ao $\mathrm{Zn}$ em experimentos onde não foram relacionados casos de diarréia como em FRYer et AL. (1992). Ao contrário, HAHN E BAKER (1993) observaram respostas positivas ao $\mathrm{zn}$ apesar dos leitões não terem apresentado diarréia. Embora a incidência de diarréia possa ser reduzida com niveis farmacológicos de $\mathrm{Zn}$, podem ocorrer melhorias na performance quando as diarréias não são problemas (SCHELI E KORNEGAY, 1996).

Embora no presente trabalho não terem sido anotadas a incidência e a severidade de diarréia, foi observada uma menor incidência de diarréia nos tratamentos que continham $\mathrm{Zn}$ em niveis superiores a 1500 ppm, principalmente nas duas primeiras semanas pós-desmama.

A eficácia do $\mathrm{Zn}$ como promotor do crescimento para os parâmetros de desempenho têm sido atribuída a efeitos equivalentes aos descritos por WALLACE (1970) E VISEK (1978) para os antibióticos e quimioterápicos.

Apesar de não ser conhecido o modo pelo qual o óxido de zinco atua, BRITo ET AL. (1993), comprovaram "in vitro" que a tolerância ao Zno de diferentes amostras da bactéria E. Coli, isoladas de casos clínicos de diarréia pós-desmame, é variável e que, de um modo geral, o Zno exerce ação inibitória sobre a bactéria. RAYMAN ET AL. (1992), citados por Bertol E BRITo (1995) relatam que o íon

RAYMAN, M.K.; LO, T.C.Y.; SANWAL, B.D. TRANSPORT OF SUCCINATE IN ESCHERICHIA COLI. Biol. ChrM., Bethesda, 246 (19): 6332-9, 1972. 

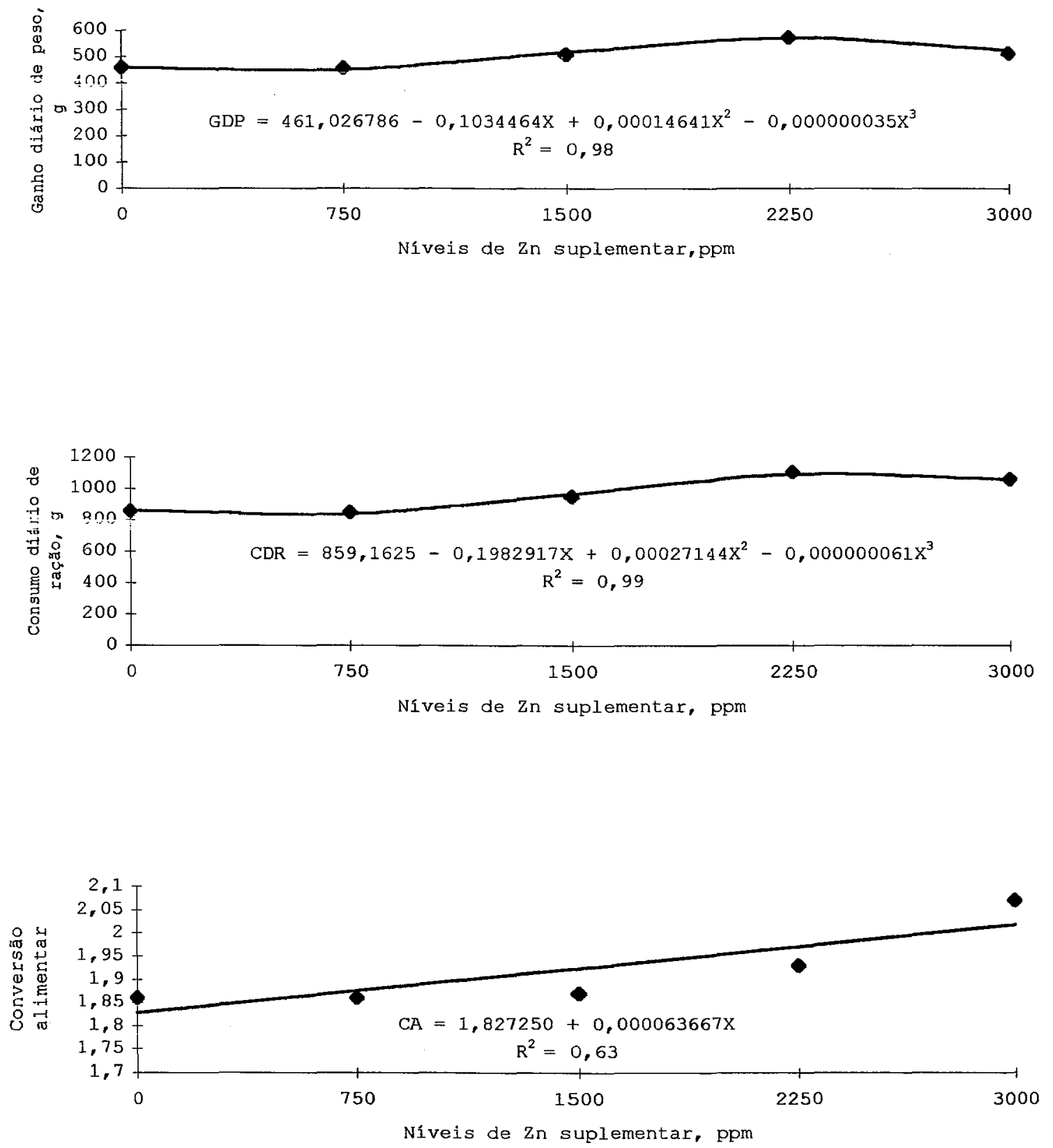

Figura 4. Efeitos dos níveis de $\mathrm{Zn}$ sobre o ganho diário de peso (GDP, g), consumo diário de ração (CDR, g) e conversão alimentar (CA) de leitões em recria durante a terceira e quarta semanas de experimentação. 

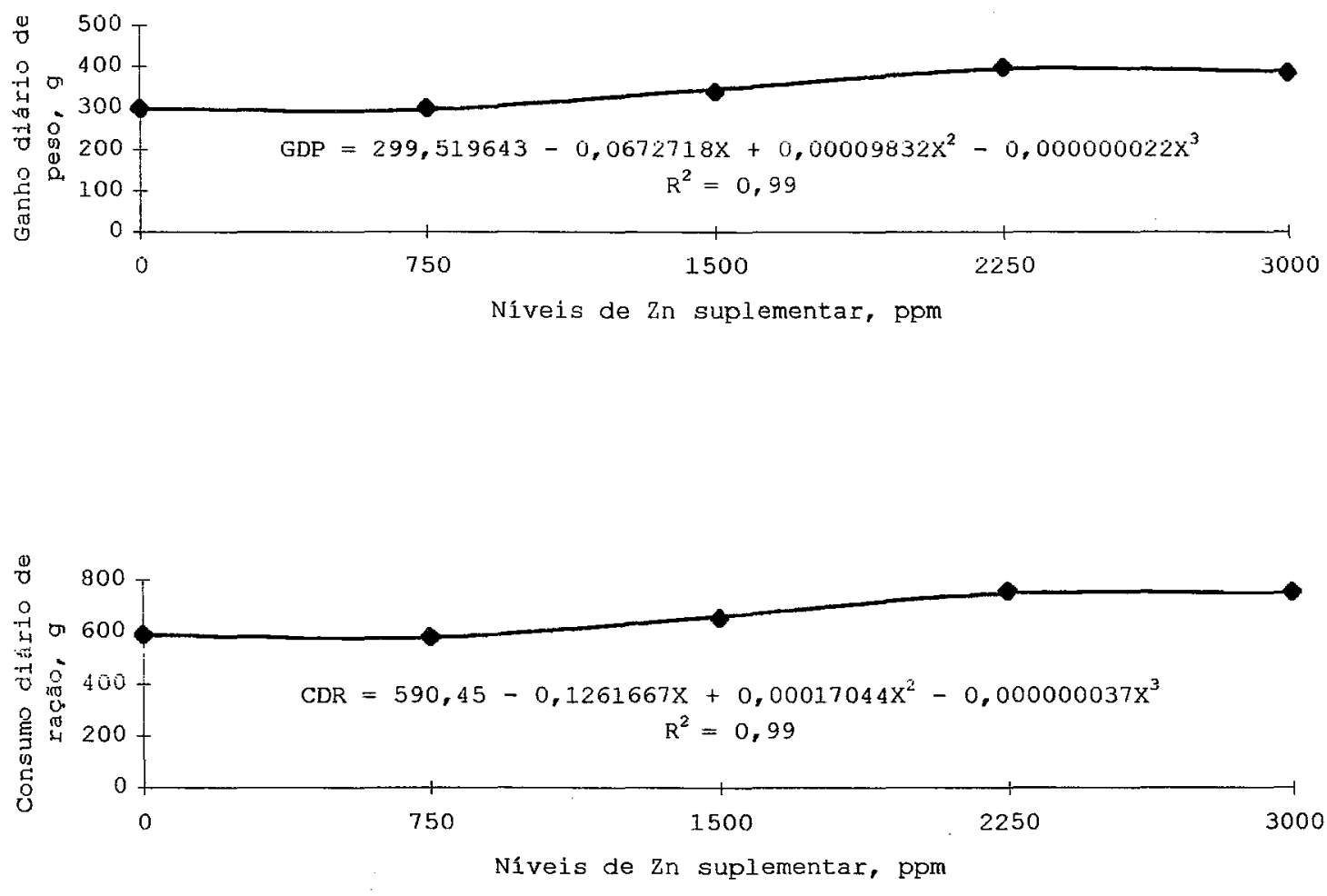

Figura 5. Efeito dos níveis de $\mathrm{Zn}$ sobre o ganho diário de peso (GDP, g) e consumo diário de ração (CDR, g) de leitões em recria durante as quatro semanas de experimentação. 
Zn inibe o transporte ativo de açúcares, aminoácidos e succinato na E. coli. KASAHARA E ANRAKU $(1972$ E 1974) observaram que o íon $\mathrm{Zn}$ bloqueia o sistema oxidase da cadeia respiratória das membranas vesiculares da E.coli mediante o bloqueio do radical - $\mathrm{SH}$ ativo, localizado na enzima succinato desidrogenase. Adicionalmente, a NADH oxidase é inibida por ataque ao resíduo histidina (KASAHARA E ANRAKU, 1974). Além disso, VeLLENGA et AL. (1992), citados por BERTOL E BRITO (1995), sugeriram que apenas uma pequena fração do $Z n$ administrado na forma de óxido de zinco é absorvido. Diante destas evidências, pode-se sugerir que a via de atuação do Zno como promotor do crescimento pode ser semelhante àquela dos principais agentes antibacterianos. - Zn atuando sobre essas bactérias do trato digestivo provavelmente ocasiona algumas modificações favoráveis ao animal hospedeiro, tais como economia de nutrientes, um menor espessamento da parede intestinal, melhorando a aborção dos nutrientes, depressão na produção de toxinas microbianas (amônia, principalmente) e controle de doenças subclínicas causadas pela $E$. coli e ou outras bactérias patogênicas (Salmonella, etc) causadoras de diarréia.

o aumento observado na taxa de crescimento dos animais que consumiram as dietas com alto nível de $\mathrm{Zn}$ também foi estimulado não só pelo aumento no consumo voluntário de alimento mas também pelo aumento na eficiência de utilização dos ingredientes da dieta, conforme observado em outros trabalhos (MENTEN ET AL., 1992; BerTol E BRITO, 1993, 1995; HAHN E BAKER, 1993; LIMA ET AL., INTERNATIONAL PIG VETERINARY SOCIETY CONGRESS, 12., HAGUE, 1992. ANAIS. HAGUE, VETERINARY SOCIETY, 1992. 
1993A; MIYADA ET AL., 1993, 1994, 1996). Entretanto, os mecanismos pelos quais o zinco estimula o consumo de ração ainda permanecem desconhecidos.

\subsection{Componentes sanguíneos e plasmáticos}

As respostas médias dos componentes sanguíneos (hematócrito e hemoglobina) e plasmáticos (proteína total, albumina $e$ uréial dos leitões ao final do período experimental são apresentados na Tabela 4. Os valores originais dos componentes sanguíneos e plasmáticos se encontram, respectivamente, nas Tabelas A6 e A7 do Apêndice.

- Zn suplementar da dieta proporcionou respostas não significativas $(P>0,05)$ dos componentes sanguíneos hematócrito e hemoglobina (Tabela 4). Os valores destes parâmetros se mantiveram dentro das faixas consideradas normais para a espécie suína (ARCHER E JEFFCOTT, 1977). Os valores normais de hematócrito e hemoglobina para suínos em recria variam na faixa de 31 a $34 \%$ e de 9,7 a 10,9 g\%, respectivamente (PReciado, 1990; Gomes, 1991). Resultados semelhantes foram observados por KLINE ET AL. (1972), HAHN E BAKER (1993) e LIMA ET AL. (1994). Os valores máximos do hematócrito e hemoglobina foram alcançados com o nivel de 2250 ppm de $\mathrm{Zn}$, apesar de não significativamente diferente $(P>0,05)$ dos demais tratamentos. De acordo com MIYADA ET AI. (1996), a diminuição dos seus valores com o nível de 3000 ppm poderia ser um indicativo de uma possivel toxidez do nivel mais alto do micromineral associada à diminuição na performance de crescimento. 
O valor do hematócrito está diretamente relacionado com o número de eritrócitos e com o conteúdo de hemoglobina do sangue (SwEnson, 1977), sendo que há indicações de que o hematócrito pode estar relacionado ao nível de lisina da ração (MIYADA, 1987). Além disso, os niveis de hematócrito e hemoglobina são indicadores do "status" nutricional de ferro dos animais (POND E MANER, 1974). Embora CoX E HALE (1962) tenham relatado que altos níveis de $Z n$ possam provocar redução na hemoglobina do sangue, no presente experimento tal fato não foi verificado. Como relatado anteriormente, os valores observados neste experimento estão dentro da faixa de normalidade, indicando que o $\mathrm{Zn}$ não interferiu no estado nutricional de ferro.

Em relação aos componentes plasmáticos, o aumento do nível de zinco na ração determinou um efeito quadrático $(\mathrm{P}<0,003)$ no conteúdo de proteínas totais, um efeito também quadrático $(\mathrm{P}<0,0004)$ no nível de albumina e um efeito linear $(\mathrm{P}<0,002)$ sobre o nivel de uréia plasmática (Tabela 5). Essas respostas estão ilustradas na Figura 6 .

O In suplementar proporcionou uma resposta quadrática $(\mathrm{P}<0,003)$ do conteúdo de proteina total do plasma. Houve uma diferença de 5,5\% em favor dos níveis de 1500 e 2250 ppm de Zn em relação ao controle. Os valores de 5,4 a $5,7 \mathrm{~g} / \mathrm{dl}$ deste experimento estão dentro dos valores considerados normais $(5,5$ a $5,8 \mathrm{~g} / \mathrm{dl})$ para suínos em recria (PRECiAdo, 1990; Gomes, 1991; Possobon, 1991). Segundo Kaneko (1980), as mudanças nos níveis de proteínas plasmáticas são lentas e de dificil detecção e interpretação quando influenciadas pela alimentação. o provável aumento de zn no sangue poderia ocasionar um aumento no nivel de proteína 
total (IIMA ET AL., 1994). O aumento nos valores de proteina total acarretaria um aumento na sintese de proteínas transportadoras de $\mathrm{Zn}$, tais como a albumina (LIMA ET AL., 1994).

Os valores de albumina encontrados para todos os niveis de $Z n$ são superiores aos valores considerados normais $(2,58 \mathrm{~g} / \mathrm{dl})$ por POND $\mathrm{E}$ MANER (1974). Entretanto, estão na faixa considerada normal por PREciado (1990), Gomes (1991) e Possobon (1991) para leitões na fase de creche. Da mesma forma que as proteínas totais, os valores máximos para a albumina foram conseguidos com 0 nível de 1500 e 2250 ppm de $\mathrm{Zn}, 13,3 \%$ superiores $(\mathrm{P}<0,05)$ aos valores encontrados com o nível de 3000 ppm. O conteúdo de albumina plasmática é considerado um indicativo do estado nutricional protéico dos animais. Os menores valores encontrados com o maior nível de $\mathrm{Zn}$, tanto para proteína total quanto para albumina, constituem outra evidência que a utilização de altos níveis do mineral em questão, por períodos prolongados, pode ter efeitos negativos no metabolismo animal.

Um nível elevado dé uréia do plasma sanguíneo pode indicar um desbalanço de aminoácidos na ração (TAYLOR ET AL., 1981, 1982), um consumo de proteínas de baixo valor biológico ou um consumo excessivo de proteínas (PUCHAI ET AL., 1962), que acarretaria perdas de nitrogênio na forma de uréia devido a uma menor síntese de proteína corporal (AlLEN, 1970). Além disso, o conteúdo de uréia plasmática é, normalmente, inversamente proporcional ao ganho de peso e eficiência alimentar dos suínos (PUCHAL ET AL., 1962).

- conteúdo de uréia do plasma aumentou linearmente $(P<0,002)$ com a adição de $\mathrm{Zn}$ na ração. O nível 
de $3000 \mathrm{ppm}$ apresentou valores 29,2\% maiores que 0 controle. Embora os níveis de uréia neste experimento estarem na faixa normal (PRECIADO, 1990; GoMes, 1991; Possobon, 1991), o aumento observado pode ser indicativo do efeito do Zn suplementar no metabolismo protéico do animal.

\section{Conclusões}

A adição do Zn suplementar, na forma de Zno, à ração de suínos em recria proporcionou uma sensível melhora na performance dos animais. A suplementação com 2250 ppm de $\mathrm{Zn}$ continuadamente por quatro semanas pós-desmama determinou melhores respostas do GDP, do $\mathrm{CDR}$ e da $\mathrm{CA}$ dos leitões. 0 melhor desempenho com o nível de $3000 \mathrm{ppm}$ até as três primeiras semanas após a desmama não se manteve até o final do experimento, muito provavelmente devido a um efeito tóxico decorrente do uso prolongado do nível mais elevado de $\mathrm{Zn}$.

- Zn dietético suplementar determinou sensiveis variações nos componentes plasmáticos dos leitões em recria. Os valores máximos observados para os componentes proteína total e albumina obtidos com o nível de 1500 ppm de $\mathrm{Zn}$ constitui outra evidência de que os níveis mais altos do mineral, por periodos prolongados, podem ter efeitos negativos no metabolismo animal. 

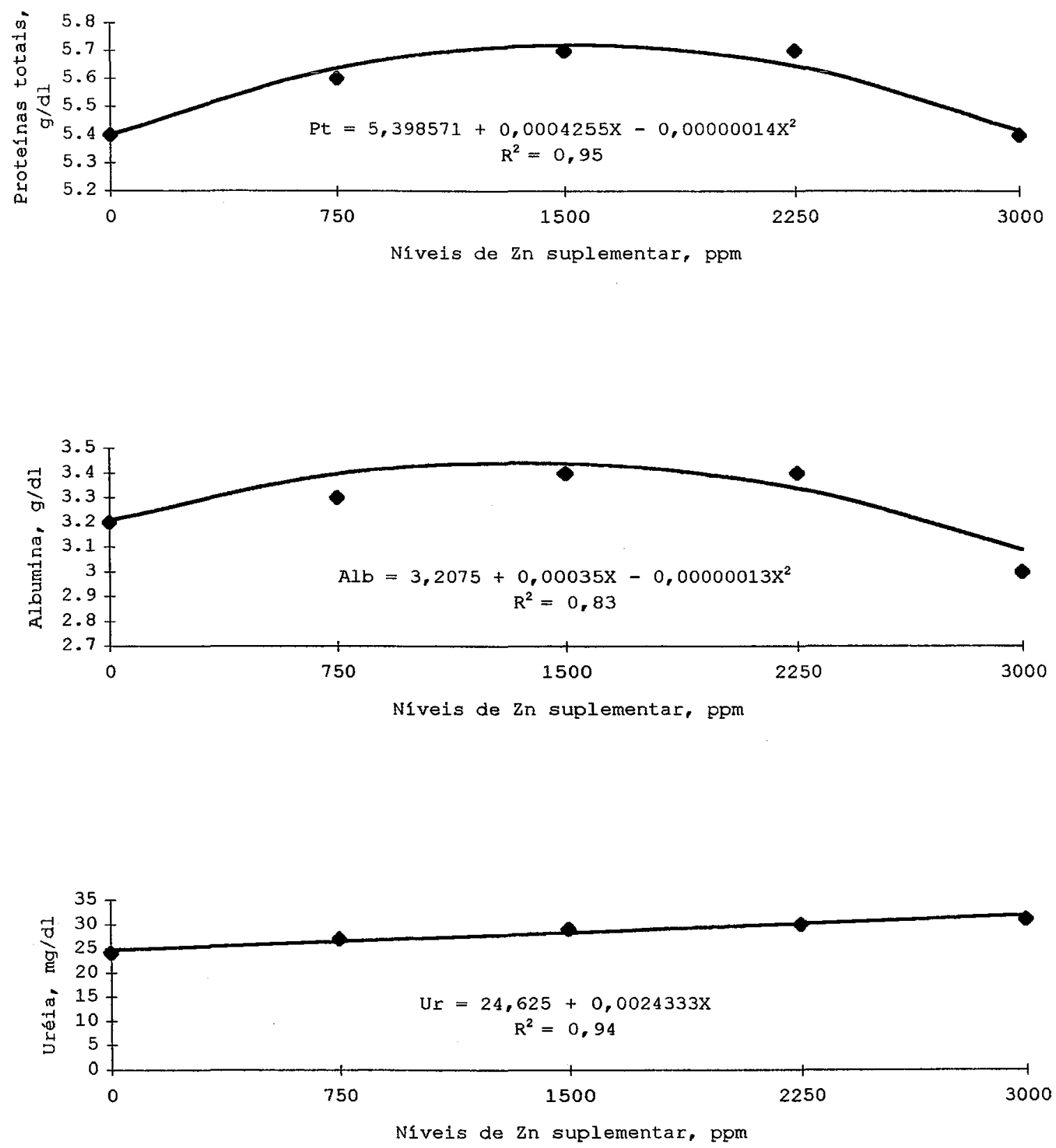

Figura 6. Efeitos dos níveis de zinco suplementar sobre a proteína total (Pt, g/dl), a albumina (Alb, g/dl) e uréia (Ur, mg/dl) do plasma de leitões em recria. 
Tabela 2. Médias das caracteristicas de performance dos leitões em recria alimentados com rações suplementadas com zinco.

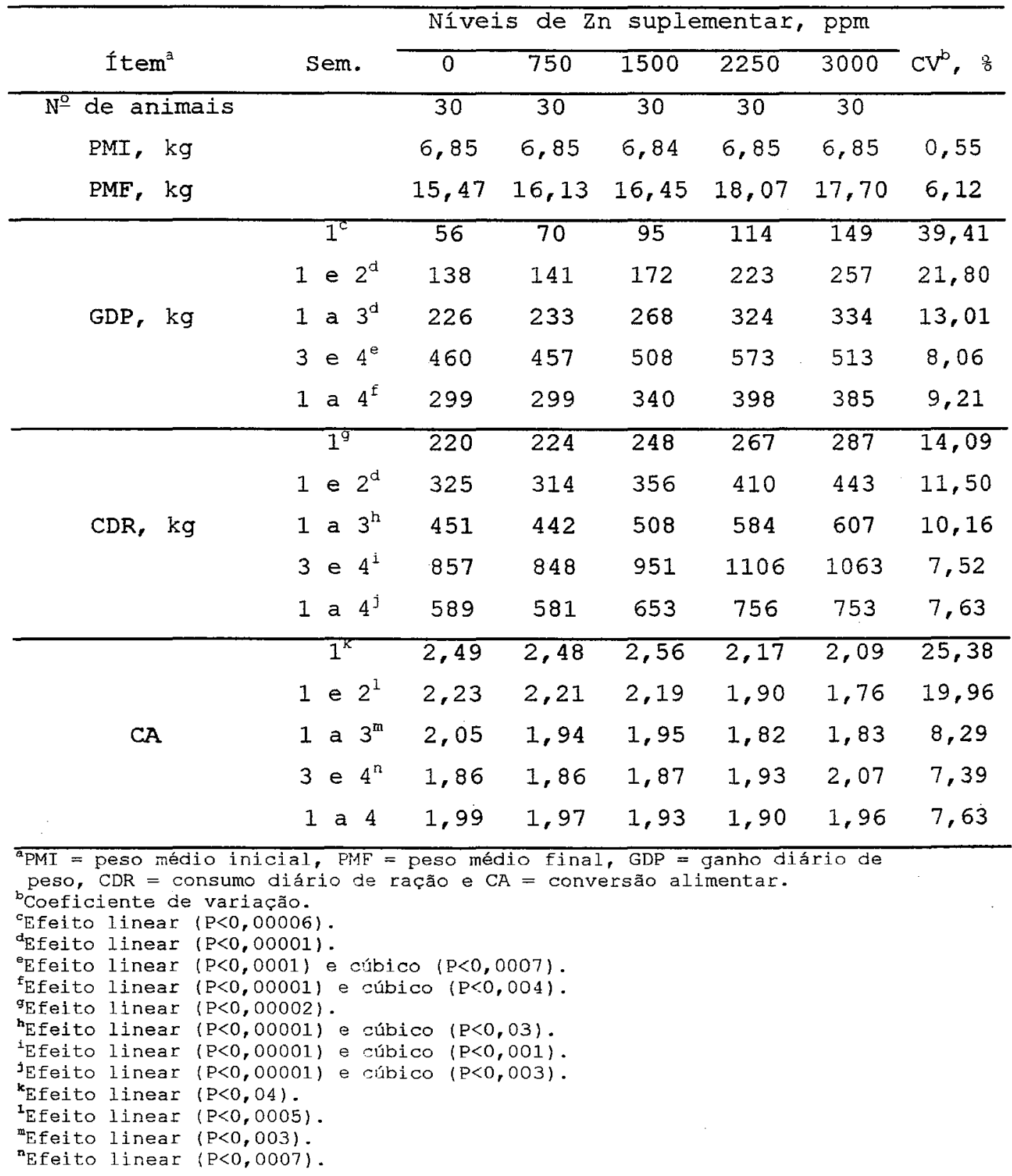




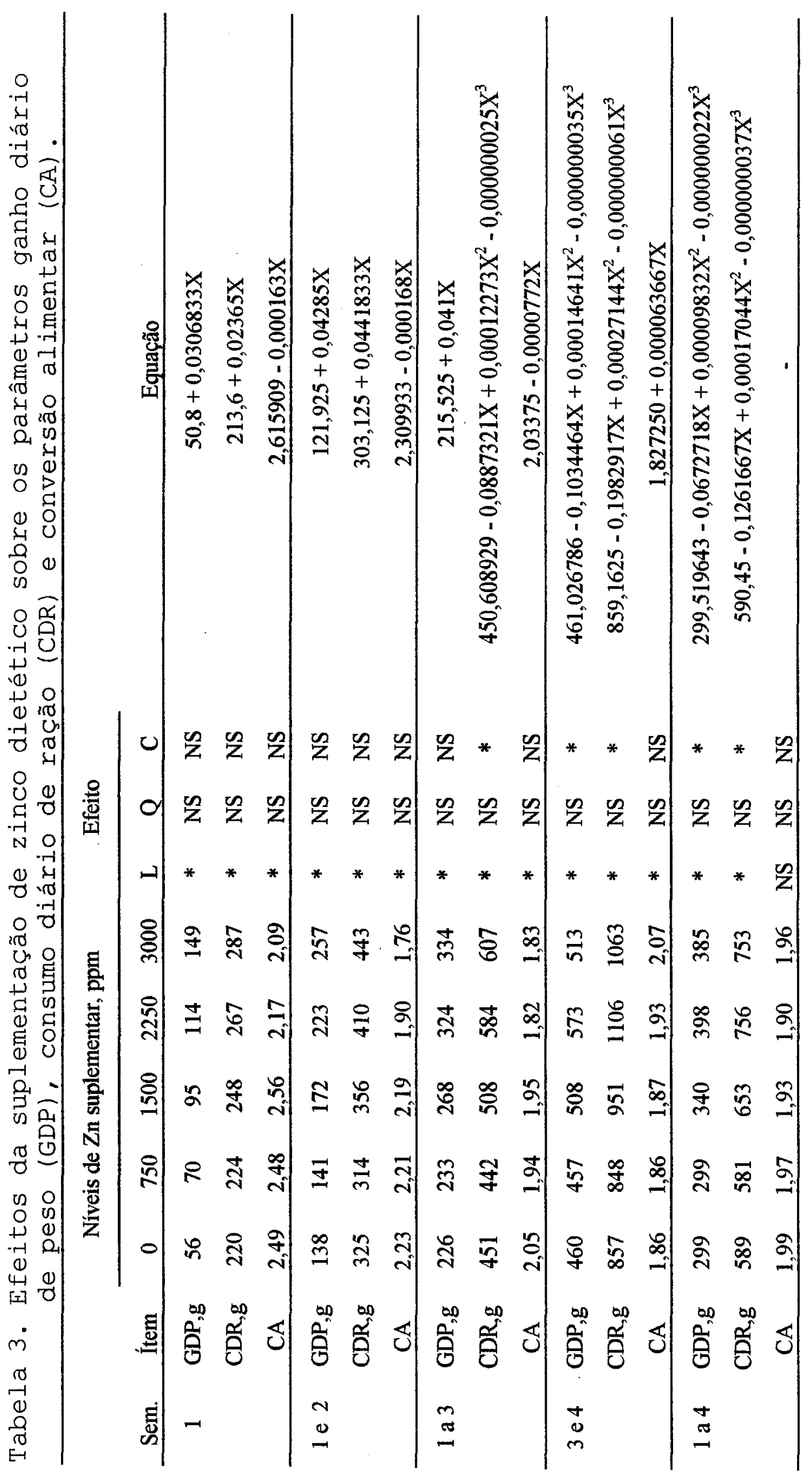


Tabela 4. Média dos componentes sanguíneos e plasmáticos dos leitões em recria alimentados com rações suplementadas com zinco.

\begin{tabular}{|c|c|c|c|c|c|c|}
\hline \multirow[b]{2}{*}{ Item $^{a}$} & \multicolumn{5}{|c|}{ Níveis de Zn suplementar, ppm } & \multirow[b]{2}{*}{$C V^{b}, \frac{q}{8}$} \\
\hline & 0 & 750 & 1500 & 2250 & 3000 & \\
\hline $\mathrm{N}^{\mathrm{O}}$ de animais & 15 & 15 & 15 & 15 & 15 & \\
\hline \multicolumn{7}{|c|}{ Componentes sanguíneos } \\
\hline Ht, o o & 35,9 & 37,2 & 36,6 & 37,6 & 37,1 & 4,55 \\
\hline $\mathrm{Hb}, \mathrm{g} / \mathrm{dl}$ & 10,7 & 11,2 & 11,0 & 11,5 & 11,2 & 5,36 \\
\hline
\end{tabular}

Componentes plasmáticos

Pt, $g / d l^{c}$

$\begin{array}{lcccccc}\mathrm{Alb}, \mathrm{g} / \mathrm{dl} \mathrm{I}^{\mathrm{d}} & 5,4 & 5,6 & 5,7 & 5,7 & 5,4 & 4,62 \\ \mathrm{Ur}, \mathrm{mg} / \mathrm{dl} \mathrm{l}^{\mathrm{e}} & 3,2 & 3,3 & 3,4 & 3,4 & 3,0 & 5,70 \\ & 24 & 27 & 29 & 30 & 31 & 16,88\end{array}$

${ }^{\mathrm{a}} \mathrm{Ht}=$ hematócrito, $\mathrm{Hb}=$ hemoglobina, $\mathrm{Pt}=$ proteína total, $\mathrm{Alb}=$ albumina e Ur = uréia.

${ }^{b}$ Coeficiente de variação.

${ }^{\complement}$ Efeito quadrático $(\mathrm{P}<0,003)$.

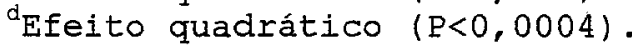

${ }^{e}$ Efeito linear $(P<0,002)$. 


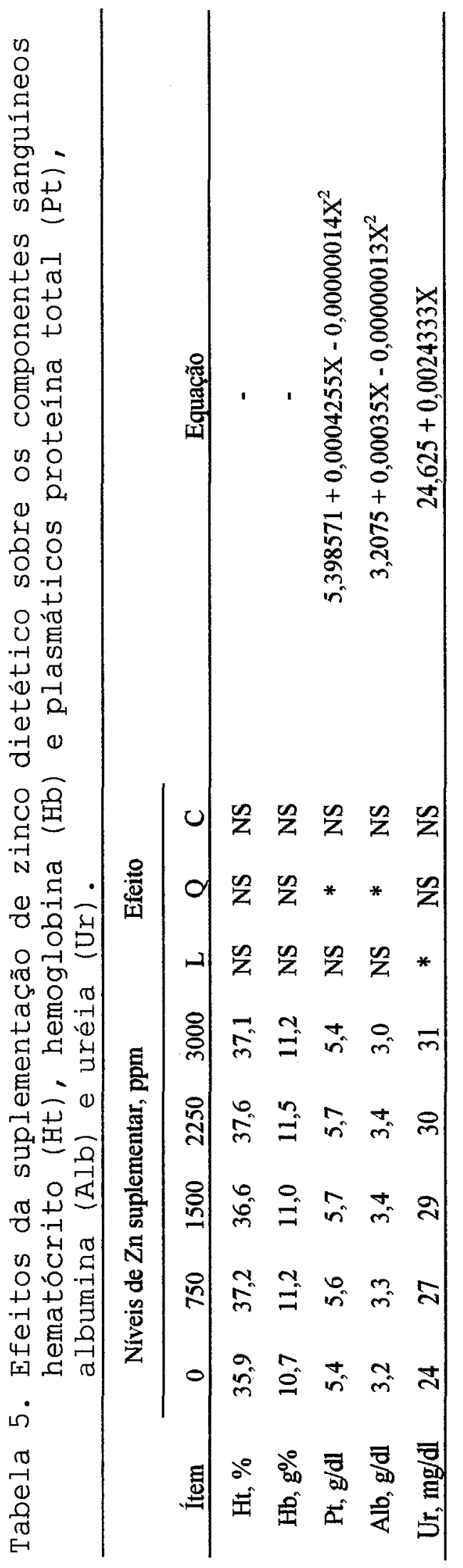




\section{REFERÊNCIAS BIBLIOGRÁFICAS}

ALLEN, R.S. Protein metabolism. In: SWENSON, M.J., ed. Duckey's physiology of domestics animals. 8.ed. Cornell, University Press, 1970. p.576-94.

ARCHER, E.R. \& JEEFCOTT, L.B. Comparative clinical haematology. Oxford, Blackwell Scientific Publications, 1977. 737p.

BARBER, R.S.; BRAUDE, R.; MITCHELI, K.G. Further studies on antibiotic, copper and zinc supplements for growing pigs. British Journal of Nutrition, Cambridge, 11: 709, 1960 .

BERTOL, T.M. \& BRITO, B.G. Efeito da redução do nível de proteína da dieta, associada a utilização do óxido de zinco, sobre desempenho e ocorrência de diarréia pósdesmame em leitões. In: CONGRESSO BRASILEIRO DE VETERINÁRIOS ESPECIALISTAS EM SUÍNOS, 6., Goiânia, 1993. Anais. Goiânia, Associação Brasileira dos Veterinários Especialistas em Suínos, 1993. p. 155.

BERTOL, T.M. \& BRITO, B.G. Efeito da retirada gradual do óxido de zinco da dieta sobre desempenho e mortalidade por doença do edema em leitões após o desmame. In: CONGRESSO BRASILEIRO DE VETERINÁRIOS ESPECIALISTAS EM SUÍNOS, 6., Goiânia, 1993. Anais. Goiânia, Associação 
Brasileira dos Veterinários Especialistas em Suínos, 1993. p.154.

BERTOL, T.M. \& BRITO, B.G. Efeito do óxido de zinco X sulfato de cobre com ou sem restrição alimentar, sobre desempenho e ocorrência de diarréia em leitões. Revista da Sociedade Brasileira de Zootecnia, Viçosa, 24 (2) : $278-88,1995$.

BRINK, M.F.; BECKER, D.E.; TERRILI, S.W.; JENSEN, A.H. ZinC toxicity in the weanling pig. Journal of Animal Science, Champaign, 18: 836-42, 1959.

BRITO, M.A.V.P.; LIMA, G.J.M.M.; BRITO, J.R.F.; MORES, N. Ação do óxido de zinco sobre amostras de Escherichia coli isoladas de suínos com diarréia pós-desmama. In: CONGRESSO BRASILEIRO DE VETERINÁRIOS ESPECIALISTAS EM SUÍNOS, 6., Goiânia, 1993. Anais. Goiânia, Associação Brasileira dos Veterinários Especialistas em Suínos, 1993. p. 157.

BUDDLE, J.R. \& BOLTON, J.R. The pathophysiology of diarrhoea in pigs. Pig News and Information, Edmonton, $13(1): 41 \mathrm{~N}-5 \mathrm{~N}, 1992$.

BUNCH, R.J.; SPEER, V.C.; HAYS, V.W̆.; HAWBAKER, J.H.; CATRON, D.V. Effects of copper sulfate, copper oxide 
and chlortetracycline on baby pig performance. Journal of Animal Science, Champaign, 20: 723-6, 1961.

BUNCH, R.J.; SPEER, V.C.; HAYS, V.W.; MCCALL, J.T. Effects of high levels of copper and chlortetracycline on performance of pigs. Journal of Animal Science, Champaign, 22: 56-60, 1963.

CABELL, C.A. \& EARLE, L.P. Additive effect of calcium and phosphorus on utilization of dietary zinc. Journal of Animal Science, Champaign, 24: 800-4, 1965.

COX, D.H. \& HALE, O.M. Liver iron depletion without copper loss in swine fed excess zinc. Journal of Nutrition, Bethesda, 77: 225-8, 1962.

DOVE, C.R. \& EWAN, R.C. Effect of excess dietary copper, iron or zinc on the tocopherol and selenium status of growing pigs. Journal of Animal Science, Champaign, 68: 2407-13, 1990.

FRYER, A.; MILLER, E.R.; KU, P.K.; ULLREY, D.E. Effect of elevated dietary zinc on growth performance of weanling swine. In: REPORT OF SWINE RESEARCH, 520., East Lansing, 1992. Anais. East Lansing, Michigan State University, 1992. p.128. 
GOMES, J.D.F. A virginiamicina como estimulante do crescimento de suínos em recria. Piracicaba, 1991. 54p. (Mestrado - Escola Superior de Agricultura "Luiz de Queiroz" / USP) .

HAHN, J.D. \& BAKER, D.H. Growth and plasma zinc responses of young pigs fed pharmacologic levels of zinc. Journal of Animal Science, Champaign, 71: 3020-4, 1993.

HALL, D. Feeding of high levels of zinc oxide found beneficial to weanling pigs. Feedstuffs, Minnetonka, $64(25): 9,1992$.

HANRAHAN, T.J. \& O'GRADY, J.T. Copper supplementation of pig diets: the effects of protein level and zinc supplementation of the response to added copper. Animal Production, Edinburg, 10: 423-32, 1968.

HARADA, Y.; HAGA, K.; OSADA, T.; KOSHINO, M. Quality of compost produced from animal wastes. Japan Agricultural Research Quarterly, Tsukuba, 26(4): 238-46, 1993. / Resumo em CAB Abstracts on CD-ROM, v.4, 1994 /.

HATHAWAY, M.R.; KRETCHMAR, C.E.; ALLEN, C.E.; CORNELIUS, S.G.; DAYTON, W.R. In vitro muscle cell proliferation and protein turnover as affected by serum from pigs fed antimicrobials. Journal of Animal Science, Champaign, 68: $3190-7,1990$. 
HILL, G.M.; KU, P.K.; MILLER, E.R.; ULLREY, D.E.; LOSTY, T.A., O'DELL, B.L. A copper deficiency in neonatal pigs induced by a high zinc maternal diet. Journal of Nutrition, Bethesda, 113: 867-72, 1983.

HOEFER, J.A.; MILLER, E.R.; ULLREY, D.E.; RITCHIE, M.D. ; LUECKE, R.W. Interrelationships between calcium, zinc, iron and copper in swine feeding. Journal of Animal Science, Champaign, 19: 249-59, 1960.

HOLM, A. E. Coli associated diarrhoea in weaner pigs: Zinkoxide added to the feed as a preventive measure? In: INTERNATIONAL PIG VETERINARY SOCIETY CONGRESS, 11, Lausanne, 1990. Anais. Lausanne, Veterinary Society, 1990. p.154.

HOLMGREN, N. Prophylactic effects of zinc oxide or olaquindox against weaning diarrhoea in pigs. SvenskVeterinartidning, Farmek, 46(5): 217-22, 1994. / Resumo em CAB Abstracts on CD-ROM, v.4, 1995 /.

HSU, F.S.; KROOK, L.; POND, W.J.; DUNCAN, J.R. Interactions of dietary calcium with toxic levels of lead and zinc in pigs. Journal of Nutrition, Bethesda, 105: 112-8, 1975 .

KANEKO, J.J. Clinical Biochemistry of Domestic Animals, 3.ed., New York, Academic Press, 1980. p.832. 
KALINOWSKY, J. \& CHAVEZ, E.R. Effect of low dietary zinc during late gestation and early lactation on the sow and neonatal piglets. Canadian Journal of Animal Science, Otawa, 64(3): 749- 58, 1984.

KASAHARA, M. \& ANRAKU, Y. Inhibition of the respiratory chain of Escherichia coli by zinc ions. Journal of Biochemistry, Tokyo , 72(3): 777-81, 1972.

KASAHARA, M. \& ANRAKU, Y. Succinate and NADH oxidase systems of Escherichia coli memorane vesicles. Mechanism of selective inhibition of the systems by zinc ions. Journal of Biochemistry, Tokyo, 76(5): 96776,1974 .

KELLOG, T.F.; HAYS, V.W.; CATRON, D.V.; QUINN, L.Y.; SPEER, V.C. Effect of dietary chemoterapeutics on the performance and fecal flora of pigs. Journal of Animal Science, Champaign, 25: 1102-6, 1966.

KLINE, R.D.; HAYS, V.W.; CROMWELL, G.L. Related effects of copper, zinc and iron on performance, hematology and copper stores of pigs. Journal of Animal Science, Champaign, 34(3): 393-6, 1972.

KYRIAKIS, S.C. New aspects of the prevention and / or treatment of the major stress induced diseases of the 
early weaned piglet. Pig News and Information, Edmonton, 10(2): 177-81, 1989.

LEWIS JÚNIOR, P.K.; HOEKSTRA, W.G.; GRRUMMER, R.H.

Restricted calcium feeding versus zinc supplementation for the control of parakeratosis in swine. Journal of Animal Science, Champaign, 16: 578-8, 1957.

LIMA, G.J.M.M. O papel do nutricionista no controle da poluição ambiental por dejetos de suínos. In: SIMPósIo LATINO AMERICANO DE NUTRIÇÃO DE SUÍNOS E AVES, Campinas, 1996. Anais. Campinas, Colégio Brasileiro de Nutrição Animal, 1996. p. 118.

LIMA, G.J.M.M.; MORES, N.; FIALHO, F.B.; BRITO, M.A.V.P.; GOMES, P.C. Efeito do período de suplementação de zinco na dieta sobre o desempenho de suínos desmamados. Revista da Sociedade Brasileira de Zootecnia, Viçosa, $23(6)$ : 949-58, 1994.

LIMA, G.J.M.M.; MORES, N.; FIALHO, F.B.; BRITO, M.A.V.P.; GOMES, P.C. Período de suplementação de zinco na dieta sobre o desempenho de suínos desmamados. In: CONGRESSO BRASILEIRO DE VETERINÁRIOS ESPECIALISTAS EM SUÍNOS, 6., Goiânia, 1993. Anais. Goiânia, Associação Brasileira dos Veterinários Especialistas em Suínos, 1993. p. 153. 
LIMA, G.J.M.M.; MORES, N.; GUIDONI, A.L.; BRITO, M.A.V.P.; zANOTTO, D.L. Níveis de suplementação de zinco na dieta sobre o desempenho de suínos desmamados. In: CONGRESSO BRASILEIRO DE VETERINÁRIOS ESPECIALISTAS EM SUINOS, 6., Goiânia, 1993. Anais. Goiânia, Associação Brasileira dos Veterinários Especialistas em Suínos, 1993. p. 156.

LIPTRAP, D.O.; MILLER, E.R.; ULLREY, D.E.; WHITENACK, D.L.; SCHOEPKE, B.L.; LUECKE, R.W. Sex influence on the zinc requirement of developing swine. Journal of Animal Science, Champaign, 30: 736-43, 1970.

LUECKE, R.W.; HOEFER, J.A.; BRAMMELL, W.S.; SCHMIDT, D.A. Calcium and zinc in parakeratosis of swine. Journal of Animal Science, Champaign, 16: 3-11, 1957.

MENTEN, J.F.M.; MIYADA, V.S.; CITRONI, A.R. Suplementação de alto nível de zinco na dieta de leitões. In: REUNIÀo ANUAL DA SOCIEDADE BRASILEIRA DE ZOOTECNIA, 29., Lavras, 1992. Anais. Lavras, Sociedade Brasileira de Zootecnia, 1992. p. 368.

MILLER, E.R.; ULLREY, D.E.; LEWIS, A.J. Swine Nutrition. 1.ed. West Laffayete, Butterworth-Heinemann, 1991. $673 p$.

MILLER, E.R.; STOWE, M.D.; KU, P.K.; HILI, G.M. Copper and zinc in swine nutrition. In: NATIONAL FEED INGREDIENTS 
ASSOCIATION. Copper and zinc in animal nutrition. Iowa, NFIA, 1979. p. 1-139.

MIYADA, V.S. A levedura seca na alimentação de suínos: Estudos adicionais sobre o seu valor protéico e vitamínico. Piracicaba, 1987. 159p. (Livre Docência Escola Superior de Agricultura "Luiz de Queiroz"/USP).

MIYADA, V.S.; MENTEN, J.F.M.; BOTELHO, F.G.A.; BEDUSCHI NETO, F. Efeitos de níveis de zinco dietético suplementar e períodos de fornecimento sobre o desempenho de leitões em recria. In: REUNIÀO ANUAL DA SOCIEDADE BRASILEIRA DE ZOOTECNIA, 33., Fortaleza, 1996. Anais. Fortaleza, Sociedade Brasileira de Zootecnia, 1996. p.113.

MIYADA, V.S.; MENTEN, J.E.M.; BEDUSCHI NETO, F.; SPERL, E.; FRANÇA, D. Níveis de zinco dietético suplementar como promotor de crescimento de leitões na fase de creche. In: REUNIÀO ANUAL DA SOCIEDADE BRASILEIRA DE ZOOTECNIA, 31., Viçosa, 1994. Anais. Viçosa, Sociedade Brasileira de Zootecnia, 1994. p.116.

MIYADA, V.S.; MENTEN, J.F.M.; PACKER, I.U.; LAVORENTI, A. Avaliação de níveis crescentes de zinco dietético suplementar como promotor do crescimento de leitões na fase de creche. In: REUNIÀO ANUAL DA SOCIEDADE BRASILEIRA DE ZOOTECNIA, 30., Rio de Janeiro, 1993. 
Anais. Rio de Janeiro, Sociedade Brasileira de Zootecnia, 1993. p.134.

MORES, N. Diarréia pós-desmama em leitões. In: MINISIMPÓSIO DO COLÉGIO BRASILEIRO DE NUTRIÇÃO ANIMAL NUTRIÇÃO E ALIMENTAÇÃO DE SUÍNOS, 10., Valinhos, 1993. Anais. Valinhos, Colégio Brasileiro de Nutrição Animal, 1993. p. 101.

NATIONAL RESEARCH COUNCIL. Mineral tolerance of domestic animals. Washington, National Academic Press, 1980. $577 p$.

NATIONAL RESEARCH COUNCIL. Nutrient requirements of swine. Washington, National Academic Press 1988. 93p.

O'DELL, B.L.; YOHE, J.M.; SAVAGE, J.E. Zinc availability in the chick as affected by phytate, calcium and ethylene diamine tetraacetate. Poultry Science, Champaign, 43: $415-9,1964$.

OLIVEIRA, P.A.V. Impacto ambiental causado pelos dejetos de suínos. In: SIMPÓSIO LATINO AMERICANO DE NUTRIÇÃO DE SUÍNOS, São Paulo, 1994. Anais. São Paulo, Colégio Brasileiro de Nutrição Animal, 1994. p. 27. 
POND, W.G. \& MANER, J.H. Swine production in temperate and tropical enviroments. San Francisco, W.H. Freeman, 1974. 646p.

POSSOBON, R.M. O cobre como estimulante do crescimento de suínos em recria. Piracicaba, 1991. 63p. (Mestrado Escola Superior de Agricultura "Luiz de Queiroz" / USP) .

POULSEN, H.D. Zinc oxide for weanling piglets. Acta Agriculturae Scandinavica, Section A, Animal Science, Tjele, 45(3): 159-67, 1995. / Resumo em CAB Abstracts on CD-ROM, V.1, $1995 /$.

PRECIADO, L.C.L. A salinomicina como estimulante do crescimento de suínos em recria. Piracicaba, 1990. 55p. (Mestrado - Escola Superior de Agricultura "Luiz de Queiroz" / USP) .

PUCHAL, F.; HAYS, V.W.; SPEER, V.C.; JONES, J.D.; CATRON, D.V. The free blood plasma aminoacids of swine as related to the source of dietary proteins. Journal of Nutrition, Bethesda, 85: 11-6, 1962.

RITCHIE, H.D.; LUECKE, R.W.; BALTZER, B.V.; MILLER, E.R.; ULLREY, D.E.; HOEFER, J.A. Copper and zinC interrelationships in the pig. Journal of Nutrition, Bethesda, 79: 117-23, 1963. 
ROSTAGNO, H.S.; SILVA, D.J.; COSTA, P.M.A.; FONSECA, J.B.; SOARES, P.R.; PEREIRA, J.A.A.; SILVA, M.A. Composição de alimentos e exigências nutricionais de aves e suínos (Tabelas brasileiras). Viçosa, Universidade Federal de Viçosa, Imprensa Universitária, 1983. 59p.

SAS INSTITUTE INC. SAS user's guide; estatistics. 5.ed. Cary: 1985. 956p.

SCHELL, T.C. \& KORNEGAY, E.T. Zinc concentration in tissues and performance of weanling pigs fed pharmacological levels of zinc from zno, zn-methionine, zn-lysine, or $\mathrm{ZnSO}_{4}$. Journal of Animal Science, Champaign, 74: 158493, 1996.

SETTLEMIRE, C.T. \& MATRONE, G. In vivo interference of zinc with ferritin iron in the rat. Journal of Nutrition, Bethesda, 92: 153-6, 1967.

SHANKLIN, S.H.; MILLER, E.R.; ULLREY, D.E.; HOEFER, J.A.; LUECKE, R.W. Zinc requirement of baby pigs on casein diets. Journal of Nutrition, Bethesda, 96: 101-7, 1968.

SHURSON, G.C.; KU, P.K.; WARLER, G.L.; YOKOYAMA, M.T.; MILLER, E.R. Physiological relationships between microbiological status and dietary copper levels in the pigs. Journal of Animal Science, Champaign, 68: 106171,1990 . 
SMITH, W.H.; PLUMLEE, M.P.; BEESON, W.M. Effect of source of protein on zinc requirement of the growing pig. Journal of Animal Science, Champaign, 21: 399-405, 1962 .

STAHLY, T.S. The role of antimicrobial agents in lean pork production. In: ANNUAL PFIZER RESEARCH CONFERENCE, 43., Lee's Summit, 1995. Anais. Lee's Summit, North American Animal Health Division Pfizer, 1995. p. 227.

STEVENSON, J.W. \& EARLE, I.P. Studies of parakeratosis in swine. Journal of Animal Science, Champaign, 15: 103645, 1956.

SUTTLE, N.F. \& MILLS, C.F. Studies of toxicity of copper to pigs. 1. Effects of oral supplements of zinc and iron salts on the development of copper toxicosis. British Journal of Nutrition, Cambridge, 20: 135-40, 1966.

SWINKELS, J.W.G.M.; BINNENDIJK, G.P.; van der PEETSCHWERING, C.M.C. Post-weaning diarrhoea of pigs as affected by dietary levels of iron and zinc. Proefverslag Proefstation voor de Varkenshouderij, Rosmalen, 1: 126-144, 1995. / Resumo em CAB Abstracts on CD-ROM, V.1, $1995 /$.

SWINKELS, J.W.G.M.; BINNENDIJK, G.P.; van der PEETSCHWERING, C.M.C.; den HARTOG, L.A. Post-weaning 
diarrhoea, performance and blood hemoglobin levels of pigs as affected by dietary levels of iron and zinc. Journal of Animal Science, Champaign, 72: 331, 1994. Supplement, 1 .

SWENSON, M.J. Physiology properties, cellular and chemical constituents of blood. In: SWENSON, M.J., ed. Ducke's physiology of domestic animals. 8. ed. Cornell University Press, 1977. p.21-61.

TAYLOR, A.J.; COLE, D.J.A.; LEWIS, D. Amino acid requirements of growing pigs. 2. Identification of the limiting amino acid(s) in aa low - protein diet supplemented with lysine. Animal Production, Edinburg, 33: 87-97, 1981 .

TAYLOR, A.J.; COLE, D.J.A.; LEWIS, D. Amino acid requirements of growing pigs. Animal Production, Edinburg, 34: 1-8, 1982 .

UNDERWOOD, E.J. Copper. In: UNDERWOOD, E.J. Trace elements in human and animal nutrition. 4.ed., New York, Ed. Academic Press, 1977. p.56-99.

VAN CAMPEN, D.R. Copper interference with the intestinal absorption of zinc - 65 by rats. Journal of Nutrition, Bethesda, 97: 104-11, 1969. 
VISEK, W.J. The mode of growth promotion by antibiotics. Journal of Animal Science, Champaign, 46(5): 1447-69, 1978 .

WALLACE, H.D. Biological responses to antibacterial feed additives in diets of meat producing animals. Journal of Animal Science, Champaign, 31: 1118-26, 1970.

WEDEKIND, K.J.; LEWIS, A.J.; GIESEMANN, M.A.; MILLER, P.S. Bioavailability of zinc from inorganic and organic sources for pigs fed corn-soyabean meal diets. Journal of Animmal Science, Champaign, 72(10): 2681-9, 1994.

ZONTA, E.P. SANEST - Sistema de análise estatística. Pelotas, Universidade Federal de Pelotas, 1983. 
APÊNDICE 
Tabela A.1. Performance dos leitões na primeira semana de experimentação.

\begin{tabular}{|c|c|c|c|c|c|c|}
\hline \multirow[b]{2}{*}{ Item ${ }^{a}$} & \multirow[b]{2}{*}{ Bloco } & \multicolumn{5}{|c|}{ Níveis de $\mathrm{Zn}$ suplementar, ppm } \\
\hline & & 0 & 750 & 1500 & 2250 & 3000 \\
\hline \multirow{9}{*}{ GDP, $g$} & 1 & 129 & 107 & 121 & 150 & 118 \\
\hline & 2 & 100 & 54 & 104 & 57 & 154 \\
\hline & 3 & 42 & 96 & 107 & 111 & 186 \\
\hline & 4 & -86 & -36 & 104 & $\begin{array}{c}111 \\
36\end{array}$ & 64 \\
\hline & 5 & 129 & 105 & 86 & 86 & 171 \\
\hline & 6 & 19 & 24 & 62 & 143 & 152 \\
\hline & 7 & 46 & 64 & 61 & 139 & 143 \\
\hline & 8 & 68 & 146 & 118 & 189 & 204 \\
\hline & Média & 56 & 70 & 95 & 114 & 149 \\
\hline \multirow{9}{*}{ CDR, $g$} & 1 & 336 & 271 & 261 & 329 & 289 \\
\hline & 2 & 214 & 218 & 221 & 239 & 321 \\
\hline & 3 & 189 & 189 & 246 & 268 & 271 \\
\hline & 4 & 125 & 161 & 307 & 200 & 229 \\
\hline & 5 & 267 & 248 & 210 & 243 & 300 \\
\hline & 6 & 190 & 195 & 233 & 286 & 290 \\
\hline & 7 & 225 & 239 & 250 & 293 & 300 \\
\hline & 8 & 214 & 268 & 254 & 278 & 296 \\
\hline & Média & 220 & 224 & 248 & 267 & 287 \\
\hline \multirow{9}{*}{$\mathrm{CA}$} & 1 & 2,61 & 2,53 & 2,15 & 2,19 & 2,42 \\
\hline & 2 & 2,14 & $(4,04)$ & 2,14 & $(4,19)$ & 2,09 \\
\hline & 3 & $(4,50)$ & 1.96 & 2,30 & 2,42 & 1,46 \\
\hline & 4 & $(-1,45)$ & $(-4,47)$ & 2,97 & $(5,56)$ & 3,56 \\
\hline & 5 & 2,07 & 2,36 & 2,44 & 2,83 & 1,75 \\
\hline & 6 & $(10,00)$ & $(8,13)$ & 3,77 & 2,00 & 1,91 \\
\hline & 7 & $(4,89)$ & 3,72 & $(4,10)$ & 2,10 & 2,10 \\
\hline & 8 & 3,16 & 1,83 & $-2,15$ & 1,47 & 1,46 \\
\hline & Média & 2,49 & 2,48 & 2,56 & 2,17 & 2,09 \\
\hline
\end{tabular}


Tabela A2. Performance dos leitões nas duas primeiras semanas de experimentação (1 a 14 dias).

\begin{tabular}{|c|c|c|c|c|c|c|}
\hline \multirow[b]{2}{*}{ Item $^{a}$} & \multirow[b]{2}{*}{ BIoco } & \multicolumn{5}{|c|}{ Níveis de $\mathrm{Zn}$ suplementar, ppm } \\
\hline & & 0 & 750 & 1500 & 2250 & 3000 \\
\hline \multirow{9}{*}{ GDP, $g$} & 1 & 152 & 109 & 168 & 200 & 191 \\
\hline & 2 & 102 & 91 & 116 & 113 & 213 \\
\hline & 3 & 95 & 171 & 175 & 227 & 282 \\
\hline & 4 & 98 & 141 & 286 & 223 & 261 \\
\hline & 5 & 255 & 200 & 165 & 264 & 333 \\
\hline & 6 & 57 & 83 & 107 & 243 & 245 \\
\hline & 7 & 163 & 118 & 170 & 271 & 220 \\
\hline & 8 & $17 \underline{9}$ & 214 & 191 & 243 & 313 \\
\hline & Média & 138 & 141 & 172 & 223 & 257 \\
\hline \multirow{9}{*}{ CDR, $g$} & 1 & 382 & 338 & 341 & 455 & 409 \\
\hline & 2 & 248 & 255 & 289 & 288 & 423 \\
\hline & 3 & 218 & 275 & 313 & 379 & 411 \\
\hline & 4 & 264 & 264 & 448 & 357 & 409 \\
\hline & 5 & 407 & 374 & 355 & 426 & 521 \\
\hline & 6 & 347 & 329 & 350 & 490 & 443 \\
\hline & 7 & 345 & 282 & 369 & 464 & 446 \\
\hline & 8 & 388 & 393 & 364 & 418 & 479 \\
\hline & Média & 325 & 314 & 356 & 410 & 443 \\
\hline \multirow{9}{*}{$\mathrm{CA}$} & 1 & 2,52 & 3,10 & 2,03 & 2,28 & 2,14 \\
\hline & 2 & 2,44 & 2,80 & 2,48 & 2,56 & 1,99 \\
\hline & 3 & 2,30 & 1,60 & 1,79 & 1,67 & 1,46 \\
\hline & 4 & 2.44 & 1,87 & 1,57 & 1,60 & 1,57 \\
\hline & 5 & 1,60 & 1,87 & 2,16 & 1,61 & 1,56 \\
\hline & 6 & $(6,09)$ & $(3,96)$ & 3,27 & 2,02 & 1,81 \\
\hline & 7 & 2,12 & 2,39 & 2,29 & 1,71 & 2,03 \\
\hline & 8 & 2,17 & 1,83 & 1,91 & 1,72 & 1,53 \\
\hline & Média & 2,23 & 2,21 & 2,19 & 1,90 & 1,76 \\
\hline
\end{tabular}


Tabela A3. Performance dos leitões nas três primeiras semanas de experimentação (1 a 21 dias).

\begin{tabular}{|c|c|c|c|c|c|c|}
\hline \multirow[b]{2}{*}{ Item ${ }^{a}$} & \multirow[b]{2}{*}{ Bloco } & \multicolumn{5}{|c|}{ Niveis de Zn suplementar, ppm } \\
\hline & & 0 & 750 & 1500 & 2250 & 3000 \\
\hline \multirow{9}{*}{ GDP, $g$} & 1 & 240 & 227 & 298 & 354 & 289 \\
\hline & 2 & 198 & 174 & 185 & 217 & 281 \\
\hline & 3 & 139 & 198 & 185 & 264 & 289 \\
\hline & 4 & 238 & 274 & 405 & 353 & 354 \\
\hline & 5 & 319 & 317 & 293 & 378 & 440 \\
\hline & 6 & 151 & 179 & 206 & 334 & 303 \\
\hline & 7 & 252 & 175 & 270 & 348 & 339 \\
\hline & 8 & 270 & 323 & 299 & 343 & 380 \\
\hline & Média & 226 & 233 & 268 & 324 & 334 \\
\hline \multirow{9}{*}{ CDR, $g$} & 1 & 486 & 443 & 512 & 620 & 548 \\
\hline & 2 & 376 & 369 & 377 & 418 & 538 \\
\hline & 3 & 310 & 401 & 393 & 517 & 533 \\
\hline & 4 & 421 & 393 & 667 & 584 & 622 \\
\hline & 5 & 560 & 570 & 556 & 657 & 751 \\
\hline & 6 & 430 & 421 & 486 & 630 & 579 \\
\hline & 7 & 473 & 367 & 537 & 651 & 631 \\
\hline & 8 & 549 & $57 \underline{5}$. & 540 & 5999 & 654 \\
\hline & Média & 451 & 442 & 508 & 584 & 607 \\
\hline \multirow{9}{*}{$\mathrm{CA}$} & 1 & 2,02 & 1,95 & 1,72 & 1,75 & 1,89 \\
\hline & 2 & 1,90 & 2,12 & 2,05 & 1,93 & 1,92 \\
\hline & 3 & 2,22 & 2,03 & 2,13 & 1.96 & 1,84 \\
\hline & 4 & 1,77 & 1,43 & 1,65 & 1,65 & 1,76 \\
\hline & 5 & 1,76 & 1,79 & 1,90 & 1,74 & 1,71 \\
\hline & 6 & 2,85 & 2,35 & 2,35 & 1,89 & 1,91 \\
\hline & 7 & 1,87 & 2,10 & 1,99 & 1,87 & 1,86 \\
\hline & 8 & 2,03 & 1,78 & 1,81 & 1,75 & 1,72 \\
\hline & Média & 2,05 & 1,94 & 1,95 & 1,82 & 1,83 \\
\hline
\end{tabular}


Tabela A4. Performance dos leitões durante as duas últimas semanas de periodo experimental (15 a 28 dias).

\begin{tabular}{|c|c|c|c|c|c|c|}
\hline \multirow[b]{2}{*}{ Item $^{a}$} & \multirow[b]{2}{*}{ Bloco } & \multicolumn{5}{|c|}{ Níveis de $\mathrm{Zn}$ suplementar, ppm } \\
\hline & & 0 & 750 & 1500 & 2250 & 3000 \\
\hline \multirow{9}{*}{ GDP, $g$} & 1 & 445 & 553 & 571 & 666 & 502 \\
\hline & 2 & 434 & 354 & 459 & 530 & 455 \\
\hline & 3 & 388 & 400 & 389 & 484 & 454 \\
\hline & 4 & 527 & 476 & 581 & 663 & 552 \\
\hline & 5 & 514 & 579 & 571 & 569 & 595 \\
\hline & 6 & 383 & 383 & 448 & 590 & 502 \\
\hline & 7 & 457 & 366 & 471 & 484 & 496 \\
\hline & 8 & 529 & $\underline{5} \underline{4} \underline{1}$. & 571. & $5 \underline{9} \underline{5}$ & $\underline{5} \underline{4} \underline{8}$ \\
\hline & Média & 460 & 457 & 508 & 573 & 513 \\
\hline \multirow{9}{*}{ CDR, $g$} & 1 & 825 & 871 & 1005 & 1138 & 957 \\
\hline & 2 & 771 & 723 & 763 & 900 & 921 \\
\hline & 3 & 670 & 809 & 686 & 925 & 907 \\
\hline & 4 & 955 & 814 & 1164 & 1226 & 1134 \\
\hline & 5 & 971 & 1083 & 1104 & 1257 & 1293 \\
\hline & 6 & 731 & 714 & 881 & 1126 & 1014 \\
\hline & 7 & 918 & 707 & 950 & 1084 & 1107 \\
\hline & 8 & 1011 & 1064 & 1057 & 1193 & 1168 \\
\hline & Média & 857 & 848 & 951 & 1106 & 1063 \\
\hline \multirow{9}{*}{$\mathrm{CA}$} & 1 & 1,86 & 1,58 & 1,76 & 1,71 & 1,91 \\
\hline & 2 & 1,78 & 2,04 & 1,66 & 1,70 & 2,02 \\
\hline & 3 & 1,73 & 2,02 & 1,77 & 1,91 & 2,00 \\
\hline & 4 & 1,81 & 1,71 & 2,00 & 1,85 & 2,05 \\
\hline & 5 & 1,89 & 1,87 & 1,93 & 2,21 & 2,17 \\
\hline & 6 & 1,91 & 1,86 & 1,97 & 1,91 & 2,02 \\
\hline & 7 & 2,01 & 1,93 & 2,02 & 2,24 & 2,23 \\
\hline & 8 & 1,91 & 1,97 & 1,85 & 2,01 & 2,13 \\
\hline & Média & 1,86 & 1,86 & 1,87 & 1,93 & 2,07 \\
\hline
\end{tabular}


Tabela A5. Performance dos leitões durante os 28 dias de período experimental (1 a 28 dias).

\begin{tabular}{|c|c|c|c|c|c|c|}
\hline \multirow[b]{2}{*}{ Item } & \multirow[b]{2}{*}{ Bloco } & \multicolumn{5}{|c|}{ Níveis de $\mathrm{Zn}$ suplementar, ppm } \\
\hline & & 0 & 750 & 1500 & 2250 & 3000 \\
\hline \multirow{9}{*}{ GDP, $\mathrm{g}$} & 1 & 298 & 331 & 370 & 433 & 346 \\
\hline & 2 & 268 & 222 & 288 & 321 & 334 \\
\hline & 3 & 241 & 286 & 281 & 355 & 367 \\
\hline & 4 & 313 & 308 & 433 & 443 & 407 \\
\hline & 5 & 385 & 389 & 368 & 416 & 464 \\
\hline & 6 & 220 & 233 & 277 & 417 & 374 \\
\hline & 7 & 310 & 242 & 321 & 378 & 358 \\
\hline & 8 & $-35 \underline{4}$ & 378 & 381. & 41 느. & $\underline{4} \underline{3} \underline{0}$ \\
\hline & Média & 299 & 299 & 340 & 398 & 385 \\
\hline \multirow{9}{*}{ CDR, $g$} & 1 & 604 & 604 & 673 & 679 & 683 \\
\hline & 2 & 510 & 489 & 525 & 694 & 672 \\
\hline & 3 & 444 & 542 & 499 & 652 & 659 \\
\hline & 4 & 597 & 539 & 806 & 792 & 772 \\
\hline & 5 & 689 & 729 & 729 & 842 & 907 \\
\hline & 6 & 539 & 521 & 615 & 808 & 729 \\
\hline & 7 & 631 & 495 & 670 & 774 & 777 \\
\hline & 8 & 700 & 729 & 711. & 805 & $82 \underline{3}$ \\
\hline & Média & 589 & 581 & 653 & 756 & 753 \\
\hline \multirow{9}{*}{$C A$} & 1 & 2,02 & 1,82 & 1,82 & 1,84 & 1,97 \\
\hline & 2 & 1.90 & 2,20 & 1,83 & 1,85 & 2,01 \\
\hline & 3 & 1,84 & 1,90 & 1,77 & 1,83 & 1,79 \\
\hline & 4 & 1,91 & 1,75 & 1,86 & 1,79 & 1,90 \\
\hline & 5 & 1,79 & 1,87 & 1,98 & 2,02 & 1,95 \\
\hline & 6 & 2,45 & 2,23 & 2,22 & 1,94 & 1,95 \\
\hline & 7 & 2,04 & 2,04 & 2,09 & 2,05 & 2,17 \\
\hline & 8 & 1,98 & 1,93 & 1,86 & 1,92 & 1,91 \\
\hline & Média & 1,99 & 1,97 & 1,93 & 1,90 & 1,96 \\
\hline
\end{tabular}


Tabela A6. Componentes sanguíneos dos leitões: hematócrito (Ht) e hemoglobina ( $\mathrm{Hb}$ ).

\begin{tabular}{|c|c|c|c|c|c|c|}
\hline \multirow[b]{2}{*}{ Ittem } & \multirow[b]{2}{*}{ Bloco } & \multicolumn{5}{|c|}{ Níveis de $\mathrm{Zn}$ suplementar, ppm } \\
\hline & & 0 & 750 & 1500 & 2250 & 3000 \\
\hline $\begin{array}{l}H t^{2} \\
\left(\frac{8}{b}\right)\end{array}$ & $\begin{array}{l}1 \\
2 \\
3 \\
4 \\
5 \\
6 \\
7 \\
8\end{array}$ & $\begin{array}{l}34,0 \\
31,5 \\
36,5 \\
35,5 \\
37,0 \\
39,5 \\
39,0 \\
34,0\end{array}$ & $\begin{array}{l}34,0 \\
33,5 \\
37,5 \\
37,5 \\
38,5 \\
40,0 \\
38,0 \\
39,0\end{array}$ & $\begin{array}{l}36,0 \\
30,0 \\
36,5 \\
40,0 \\
38,0 \\
41,5 \\
35,0 \\
35,5\end{array}$ & $\begin{array}{l}33,0 \\
32,0 \\
38,5 \\
38,5 \\
41,5 \\
40,5 \\
38,0 \\
39,0\end{array}$ & $\begin{array}{l}34,5 \\
33,5 \\
36,5 \\
40,5 \\
41,5 \\
36,5 \\
36,5 \\
37,5\end{array}$ \\
\hline $\begin{array}{l}\mathrm{Hb}^{\mathrm{a}} \\
\left(g^{\frac{o}{b}}\right)\end{array}$ & $\begin{array}{c}\text { Média } \\
1 \\
2 \\
3 \\
4 \\
5 \\
6 \\
7 \\
8 \\
\end{array}$ & $\begin{array}{c}35,9 \\
11,2 \\
9,9 \\
10,4 \\
10,2 \\
10,9 \\
11,2 \\
11,9 \\
10,3\end{array}$ & $\begin{array}{l}37,2 \\
11,0 \\
10,4 \\
10,8 \\
11,6 \\
11,2 \\
11,4 \\
11,6 \\
11,7\end{array}$ & $\begin{array}{c}36,6 \\
11,6 \\
9,3 \\
10,9 \\
12,4 \\
11,2 \\
11,1 \\
10,6 \\
11,0\end{array}$ & $\begin{array}{l}37,6 \\
10,5 \\
10,3 \\
11,6 \\
11,7 \\
12,6 \\
11,8 \\
11,7 \\
11,9\end{array}$ & $\begin{array}{r}37,1 \\
11,1 \\
10,5 \\
11,3 \\
11,9 \\
12,5 \\
9,9 \\
11,1 \\
11,1\end{array}$ \\
\hline & Média & 10,7 & 11,2 & 11,0 & 11,5 & 11,2 \\
\hline
\end{tabular}

Valores individuais representam as médias de dois animais de cada baia. 
Tabela A7. Componentes plasmáticos dos leitões: proteína total (Pt), albumina (Alb) e uréia (Ur).

\begin{tabular}{|c|c|c|c|c|c|c|}
\hline \multirow[b]{2}{*}{ Ítem } & \multirow[b]{2}{*}{ Bloco } & \multicolumn{5}{|c|}{ Níveis de $\mathrm{Zn}$ suplementar, ppm } \\
\hline & & 0 & 750 & 1500 & 2250 & 3000 \\
\hline \multirow[t]{2}{*}{$\begin{array}{c}\mathrm{Pt}^{\mathrm{a}} \\
(\mathrm{g} / \mathrm{d} I)\end{array}$} & $\begin{array}{l}1 \\
2 \\
3 \\
4 \\
5 \\
6 \\
7 \\
8 \\
\end{array}$ & $\begin{array}{l}5,4 \\
4,9 \\
5,0 \\
5,8 \\
5,2 \\
4,9 \\
6,4 \\
5,6\end{array}$ & $\begin{array}{l}5,7 \\
5,6 \\
5,6 \\
5,6 \\
5,9 \\
5,7 \\
5,5 \\
5,6\end{array}$ & $\begin{array}{l}5,7 \\
5,2 \\
5,6 \\
6,1 \\
5,7 \\
5,5 \\
5,8 \\
5,8\end{array}$ & $\begin{array}{l}5,6 \\
5,1 \\
5,6 \\
5,7 \\
6,0 \\
5,4 \\
5,8 \\
6,3\end{array}$ & $\begin{array}{l}5,6 \\
5,0 \\
5,3 \\
5,5 \\
5,5 \\
5,0 \\
5,7 \\
5,5\end{array}$ \\
\hline & Média & 5,4 & 5,7 & 5,7 & 5,7 & 5,4 \\
\hline \multirow[t]{2}{*}{$\begin{array}{c}A l b^{a} \\
(g / d I)\end{array}$} & $\begin{array}{l}1 \\
2 \\
3 \\
4 \\
5 \\
6 \\
7 \\
8 \\
-\end{array}$ & $\begin{array}{l}3,3 \\
2,9 \\
2,9 \\
3,3 \\
3,3 \\
3,0 \\
3,6 \\
3,7\end{array}$ & $\begin{array}{l}3,1 \\
2,8 \\
3,1 \\
3,5 \\
3,7 \\
3,0 \\
3,3 \\
4,0\end{array}$ & $\begin{array}{c}3,3 \\
2,7 \\
3,7 \\
3,7 \\
3,7 \\
3,2 \\
3,3 \\
4,0\end{array}$ & $\begin{array}{l}3,0 \\
3,0 \\
3,6 \\
3,3 \\
3,4 \\
3,3 \\
3,5 \\
4,2\end{array}$ & $\begin{array}{l}3,0 \\
2,3 \\
3,1 \\
3,2 \\
3,3 \\
2,7 \\
3,0 \\
3,5\end{array}$ \\
\hline & Média & 3,2 & 3,3 & 3,4 & 3,4 & 3,0 \\
\hline \multirow{9}{*}{$\begin{array}{c}U r^{a} \\
(m g / d l)\end{array}$} & 1 & 24 & 15 & 20 & 25 & 22 \\
\hline & 2 & 21 & 22 & 28 & 25 & 27 \\
\hline & 3 & 23 & 16 & 34 & 30 & 24 \\
\hline & 4 & 25 & 29 & 33 & 27 & 25 \\
\hline & 5 & 21 & 30 & 25 & 32 & 40 \\
\hline & 6 & 22 & 27 & 27 & 32 & 38 \\
\hline & 7 & 21 & 39 & 35 & 34 & 35 \\
\hline & 8 & $3 \underline{4}$ & 36 & 31 & 39 & 38 \\
\hline & Média & 24 & 27 & 29 & 31 & 31 \\
\hline
\end{tabular}

${ }^{\mathrm{a}} \mathrm{Valores}$ individuais correspondem a amostras compostas de

plasma de dois animais de cada baia. 